\author{
UNIVERSIDADE DE SÃO PAULO \\ FACULDADE DE ZOOTECNIA E ENGENHARIA DE ALIMENTOS
}

Ana Laura Januário Lelis

Evaluation of forage production and performance of Nellore heifers in different grazing methods and supplementation as a strategy to mitigate methane emissions 
Ana Laura Januário Lelis

\section{Evaluation of forage production and performance of Nellore heifers in different grazing methods and supplementation as a strategy to mitigate methane emissions}

\section{Versão Corrigida}

Dissertation presented to the College of Animal Science and Food Engineering of the University of Sao Paulo, as part of the requirements for obtaining the Master's degree in Sciences from the postgraduate program in Animal Science

Area of concentration: Animal Productivity and Quality

Advisor: Prof. Paulo Henrique Mazza Rodrigues, Ph.D.

Co-advisor: Patrícia Perondi Anchão Oliveira, Ph.D. 
International Cataloging Data in Publication

Cataloging sheet elaborated by the Library and Information Service, FZEA / USP

J541e

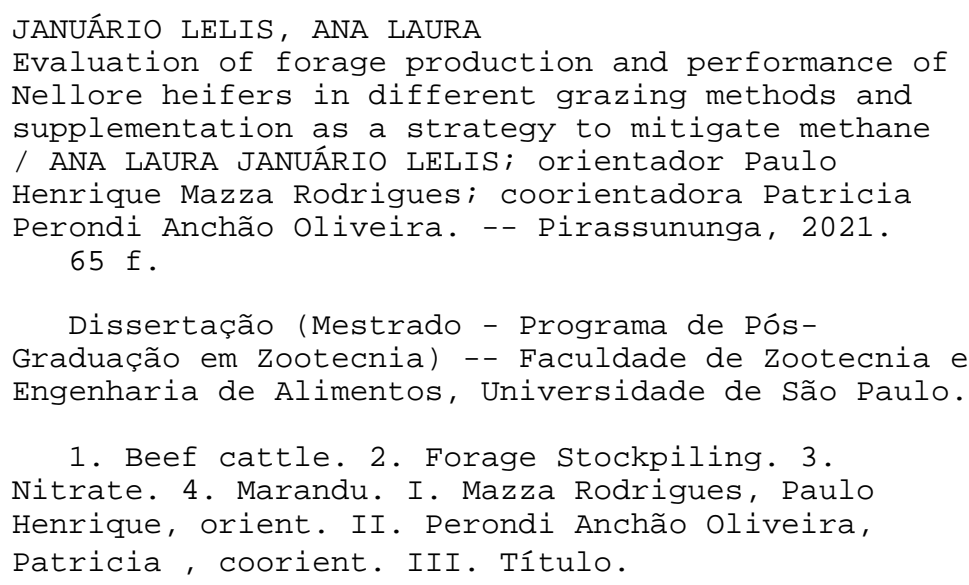

Permission to copy this document, in whole or in part, provided that the source is cited - the author 
AUTHOR: LELIS, Ana Laura Januário

TITLE: Evaluation of forage production and performance of Nellore heifers in different grazing methods and supplementation as a strategy to mitigate methane emissions

Dissertation presented to the College of Animal Science and Food Engineering of the University of Sao Paulo, as part of the requirements for obtaining the Master's degree in Sciences from the postgraduate program in Animal Science.

Area of concentration: Animal Productivity and Quality.

Advisor: Prof. Paulo Henrique Mazza Rodrigues, Ph.D.

Co-advisor: Patrícia Perondi Anchão Oliveira, Ph.D.

Date: $14 / 05 / 2021$

\section{Examination Board}

Prof. Dr. Paulo Henrique Mazza Rodrigues Institution: FMVZ/USP - Pirassununga.

Verdict: Signature:

Prof. Dr. Valdo Rodrigues Herling Institution: FZEA/USP - Pirassununga.

Verdict: Signature:

Prof. Dr. Antonio Pinheiro Faciola - University of Florida - Gainesville FL USA.

Verdict: Signature:

Dra. Virgínia Lucia Neves Brandão Institution: Dairy Technical Manager at Micronutrients USA.

Verdict: Signature: 


\section{ACKNOWLEDGEMENTS}

I thank God who guides me every day.

I thank my family for their support and unity, but mainly, for being the foundation and pillars of my life. My parents have always encouraged and supported me in all my choices and decisions, I will be forever grateful to them.

I thank Professor Paulo Henrique Mazza Rodrigues for the support and teachings, but even more for the example of a person that you are. For always being available to help, for your contributions, corrections, for believing in my potential and giving me the opportunity for personal and professional growth.

I thank FZEA, Department of Animal Science, for giving me the opportunity to execute my master's degree.

To my Co-advisor, Patrícia Perondi Anchão Oliveira, for supporting.

To my co-workers, who are now my friends, Ana, Murilo and Willian, you made the walk lighter, our moments were kept in my memory.

To interns Bruna, Bárbara and Júlia for their immense help.

The Master's scholarship granted by the São Paulo Research Foundation (FAPESP) - process number: 2019 / 11429-4.

Finally, I would like to thank everyone I have not mentioned, who directly or indirectly contributed to making this dream come true. 


\section{RESUMO}

LELIS, A. L. J. Avaliação da produção de forragem e desempenho de novilhas Nelore em diferentes métodos de pastejo e suplementação como estratégia para mitigar as emissões de metano. 2021. 65 p. Dissertação (Mestrado) - Faculdade de Zootecnia e Engenharia de Alimentos, Universidade de São Paulo, Pirassununga, 2021.

Brasil ocupa posição de destaque na pecuária, sendo considerado um dos mais importantes fornecedores de carne bovina do mundo. Para atender à demanda de uma população em crescimento, o setor pecuário precisa aumentar sua produção com eficiência, reduzindo o impacto ambiental, que tem recebido inúmeras críticas na produção animal. Para produzir com sustentabilidade, é necessário melhorar a produtividade, por meio do manejo adequado de pastagens e estratégias que reduzam o efeito sazonal da produção de forragem em determinadas épocas do ano. Uma das estratégias que podem ser adotadas para reduzir o efeito da baixa disponibilidade de forragem, devido à sazonalidade, são as pastagens diferidas associadas à suplementação nutricional, que visam melhorar a eficiência animal e reduzir as emissões de metano no meio ambiente. $\mathrm{O}$ objetivo deste estudo foi investigar, ao longo do ano, os efeitos dos métodos de pastejo (rotacionado e diferido) sobre o potencial de produção de forragem, valor nutricional da forragem e resposta animal de novilhas recebendo duas fontes de nitrogênio. $\mathrm{O}$ estudo foi conduzido em Pirassununga - SP, Brasil. As unidades experimentais consistem em 8 módulos. Cada tratamento foi distribuído em 2 módulos, em delineamento de blocos casualizados. Foram utilizadas 24 novilhas Nelore (6 animais/tratamento). Os tratamentos consistiram em dois métodos de pastejo (diferido e rotacionado) e suplementos nitrogenados (urea e nitrato de amônio) em arranjo fatorial 2 x 2:1) pastagem diferida com suplementação de ureia; 2) pastagem diferida com suplementação de nitrato de amônio; 3) pastagem rotacionada com suplementação de ureia e 4) pastagem rotacionada com suplementação de nitrato de amônio. O experimento durou um ano. Os dados foram analisados estatisticamente utilizando o SAS 9.3 (SAS Institute Inc., Cary, NC, EUA), considerando como efeitos significativos quando $\mathrm{P} \leq 0,05$. Houve diferenças na produção de forragem, componentes morfológicos e valor nutricional entre os métodos de pastejo nas estações. No entanto, essas diferenças não influenciaram na resposta final do desempenho das novilhas, sendo semelhantes entre os métodos de pastejo. A fonte de nitrogênio não impactou a produção de $\mathrm{CH}_{4}$.

Palavras-chave: Bovinos de Corte; Diferimento; Nitrato; Marandu. 


\begin{abstract}
LELIS, A. L. J. Evaluation of forage production and performance of Nellore heifers in different grazing methods and supplementation as a strategy to mitigate methane emissions. $2021.65 \mathrm{f}$. f. M.Sc. Dissertation - Faculdade de Zootecnia e Engenharia de Alimentos, Universidade de São Paulo, Pirassununga, 2021.

Brazil occupies a prominent position in in livestock production, being considered one of the most important beef suppliers in the world. In order to meet the demand of a growing population, the livestock sector needs to increase its production efficiently, reducing the environmental impact, which has received numerous criticisms in animal production. In order to produce with sustainability, it is necessary to improve productivity, through adequate management of pastures and strategies that reduce the seasonal effect of forage production during certain seasons of the year. One of the strategies that can be adopted to reduce the effect of low forage availability due to seasonality is the deferred pastures associated with nutritional supplementation, which aims to improve animal efficiency and reduce the methane emission to the environmental. The objective of this study was to investigate, throughout the year, the effects of grazing methods (rotated and deferred) on the forage production potential, forage nutritional value and animal response of heifers receiving two sources of nitrogen. The study was conducted in Pirassununga - SP, Brazil. The experimental units consisted of 8 modules. Each treatment was allotted to 2 modules in a randomized block design. Twenty-four Nellore heifers (6 animals/treatment) were used. The treatments consisted of two grazing methods (deferred and rotate) and two nitrogen supplements (urea and ammonium nitrate) in a $2 \times 2$ factorial arrangement: 1) deferred grazing plus urea supplementation; 2) deferred grazing plus ammonium nitrate supplementation; 3) rotated grazing plus urea supplementation and 4) rotated grazing plus ammonium nitrate supplementation. The experiment lasted 1 year. The data were statistically analyzed using SAS 9.3 (SAS Institute Inc., Cary, NC, USA), considering as significant effects when $\mathrm{P} \leq 0.05$. However, these differences did not influence the final response of heifers' performance, being similar between grazing methods. The nitrogen source did not impact $\mathrm{CH}_{4}$ production.
\end{abstract}

Key words: Beef cattle; Forage Stockpiling; Nitrate; Marandu. 


\section{Summary}

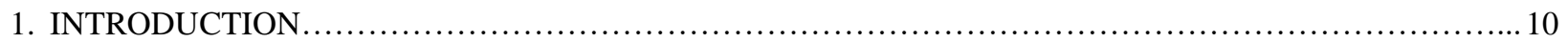

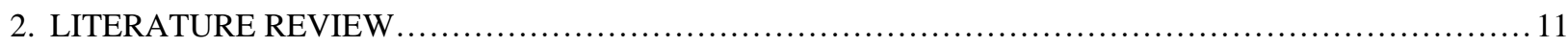

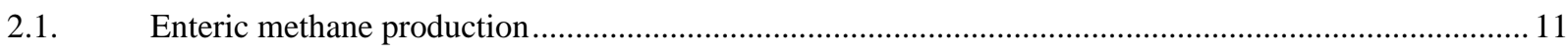

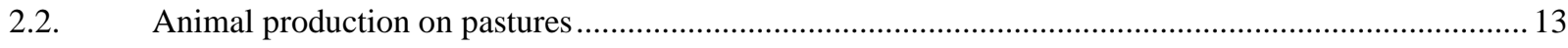

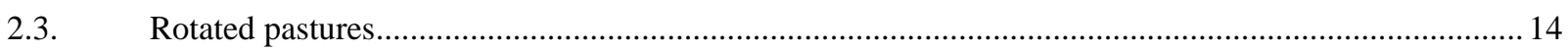

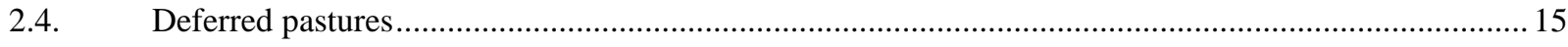

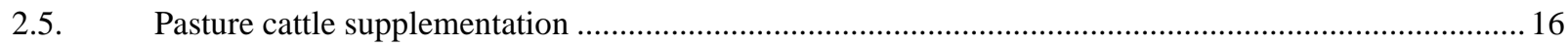

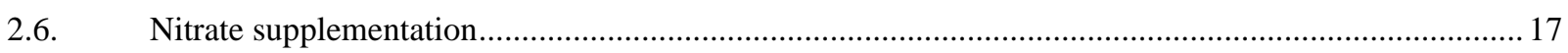

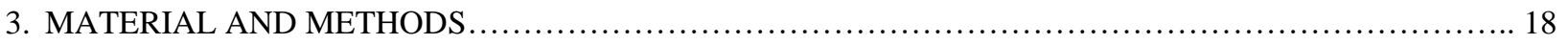

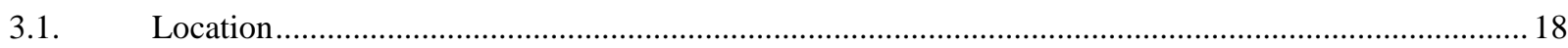

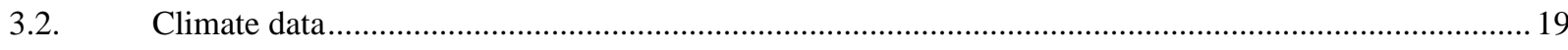

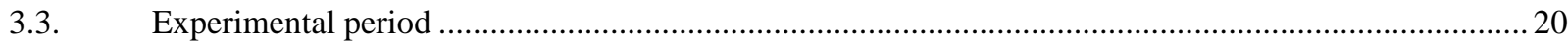

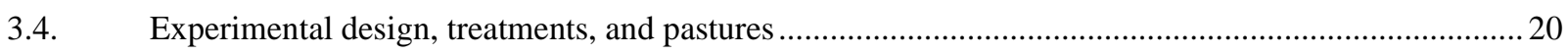

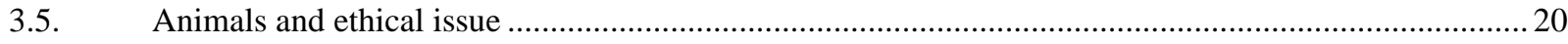

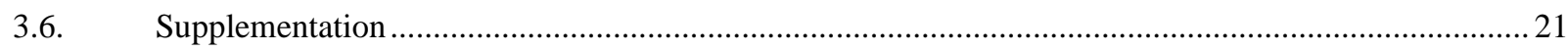

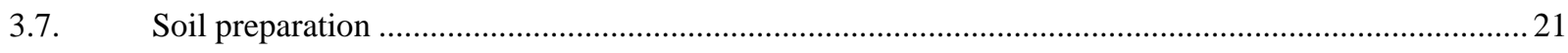

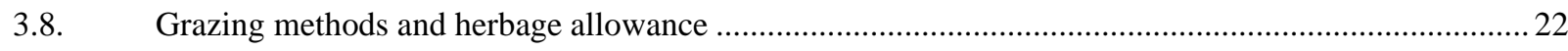

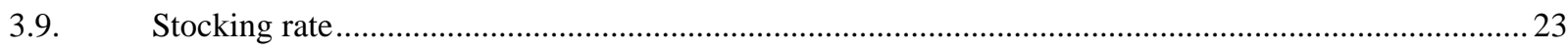

3.10. Procedures for sampling, evaluation, and nutritional value of forage .........................................23

3.10.1. Characterization of pasture productive components ............................................................23

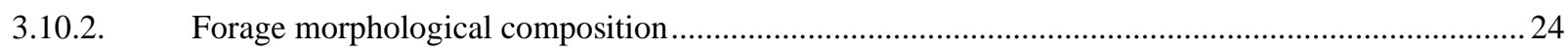

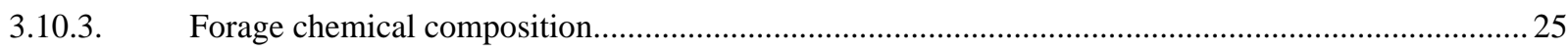

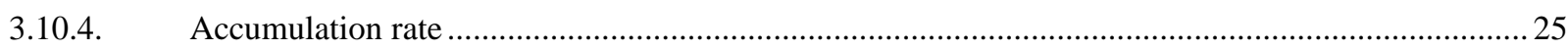

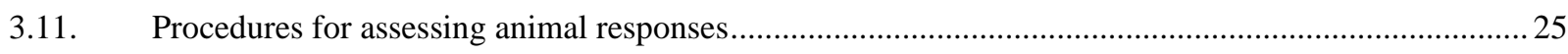

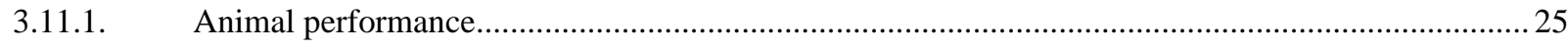

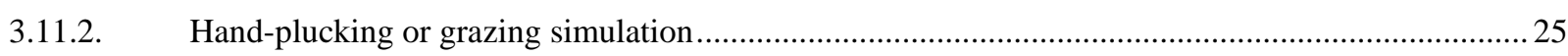




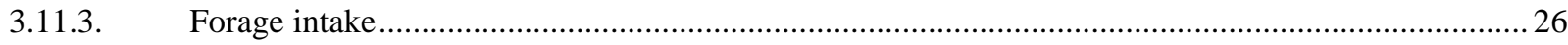

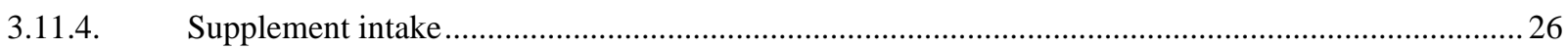

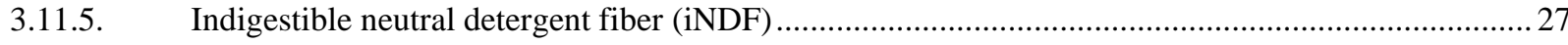

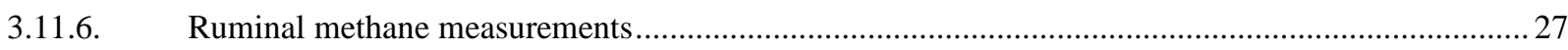

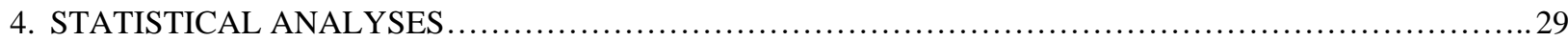

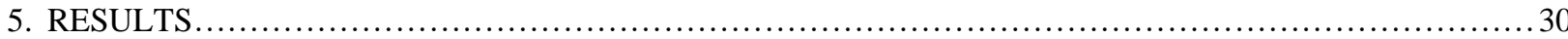

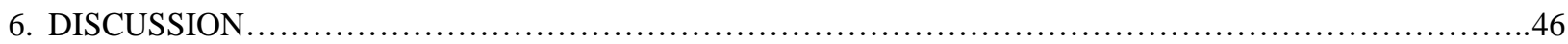

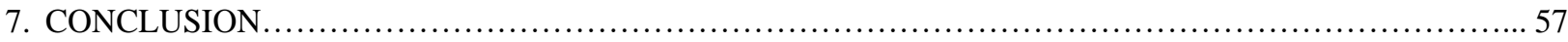

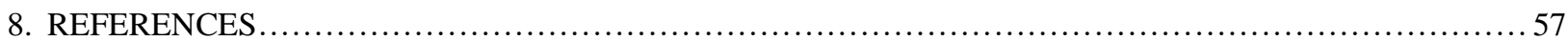




\section{INTRODUCTION}

Brazil occupies a leading position in the beef meat sector, with currently 214.69 million heads; is exporter leader and the second largest beef producer in the world (ABIEC, 2020). Significant proportion of the cattle herd consists of heifers from one to three years old (SEMMELMANN et al., 2001) and Zebu animals (Bos taurus indicus), of which $80 \%$ is Nellore breed (ABCZ, 2019).

The national livestock is based on pastures, which comprises approximately 170 million hectares of grasslands (BUSTAMANTE et al., 2012), mainly of the genus Urochloa, representing more than $70 \%$ of the cultivated pasture area (HEINRICHS et al., 2012), and of these, the largest part is formed by $U$. brizantha $\mathrm{cv}$. Marandu, as it is considered the most economical manner to feed cattle with high availability, adaptability and productivity in tropical climate conditions (CABRAL et al., 2014; DEMARCHI et al., 2016).

However, due to the physiological characteristics of tropical forages and climatic conditions throughout the year, forage production is seasonal, with pasture growth occurring across rainy season (November-March), followed by a senescent period throughout an extended dry season (AprilOctober) (SANTOS et al., 2009).

During the dry season, the nutritional quality of forage decreases, increasing structural carbohydrates and reducing crude protein content, resulting in lower voluntary intake and diet digestibility. Such factors reduce animal performance and contribute to increased enteric methane emissions, either expressed in its relation to the consumed forage or in relation to the final product generated (ARCHIMEDE et al., 2011). Therefore, strategies to overcome this situation are necessary in most livestock production systems.

Pasture deferred is a storage strategy, which has often been defined as the discontinuation of pasture use at the end of the forage growing season for a specific period, to allow forage material accumulation that can be used during periods of forage scarcity such as dry season (EUCLIDES, 2007). However, beef cattle allotted on deferred pasture may express lower performance and increased enteric methane emissions, due to low nutritional quality, greater accumulation of dead material and stem from deferred pastures (SANTOS et al., 2004). 
In order to increase animal performance, a supplementation strategy can be adopted to adjust the nutritional value of available forage and/or improve feed conversion of animals in deferred pastures (EUCLIDES; MEDEIROS, 2005).

Nitrate is a source of non-protein nitrogen that has demonstrated an effective methane mitigation strategy (HRISTOV, 2013). In addition, it is a hydrogen sink in rumen and when provided to animals, has the potential to decrease rumen methane emissions by reducing its formation (LENG; PRESTON, 2010).

Methane production from cattle has been the focus of research due to environmental concerns associated with increased greenhouse gases emissions. Evaluation of performance of animals receiving ammonium nitrate in grazing systems is still scarce in the literature. For this reason, strategies that improve animal and pasture efficiency resulting in superior final product quality and reduce environmental damage should be encouraged.

Given these factors, the hypothesis of this study is that different grazing methods combined with supplementation alter the animal response and the use of ammonium nitrate as a feed supplement reduces the production of enteric methane, with a positive impact in the different production systems, especially in those with higher stocking rates and, therefore, higher emissions of enteric methane per area. Therefore, the objective is to investigate throughout the year, the effects of grazing methods (rotated and deferred) on the potential forage production, nutritional value of forage and animal response of heifers receiving two nitrogen sources.

\section{LITERATURE REVIEW}

\subsection{Enteric methane production}

Currently, agriculture plays an important role in global environmental problems, such as climate changes, land degradation, water pollution and biodiversity loss (FAO, 2013; ROJASDOWNING et al., 2017). Despite the widespread recognition of the importance of agriculture in food production and income generation, livestock emits significant amounts of greenhouse gases (GHG), mainly in regions where this activity is based on degraded or seasonal natural pastures and characterized by low productivity and higher GHG production rate (IPCC, 2007).

Among the GHG, carbon dioxide $\left(\mathrm{CO}_{2}\right)$, methane $\left(\mathrm{CH}_{4}\right)$ and nitrous oxide $\left(\mathrm{N}_{2} \mathrm{O}\right)$ are the most important in agriculture. The concentrations of $\mathrm{CH}_{4}$ and $\mathrm{N}_{2} \mathrm{O}$ in the atmosphere are lower than that 
of $\mathrm{CO}_{2}$; however, these gases have a heating potential of 25 and 298 times more than $\mathrm{CO}_{2}$, respectively (IPCC, 2007). The animals can contribute to the increase of $\mathrm{CH}_{4}$ concentration through two main forms: enteric fermentation (85 to 90\%) and fermentation of organic waste (NOVAK; FIORELLI, 2010).

Brazilian enteric methane emissions correspond to $63.3 \%$ of anthropogenic emissions of this gas $(54.1 \%$ from beef cattle, $7.4 \%$ from dairy cattle and $1.9 \%$ from other species), while the decomposition of manure corresponds to $5.5 \%$ of those emissions (BRAZIL, 2009). According to Berchielli et al. (2012), the Brazilian bovine herd is responsible for approximately $3.3 \%$ of the methane produced worldwide by human activities, $11.3 \%$ of the enteric methane produced in the world.

Ruminants produce methane as an inevitable by-product of ruminal fermentation of carbohydrates, proteins and other organic polymers contained in feeds (ODONGO et al., 2007). The microbial fermentation to obtain energy by ruminal bacteria leads to the production of short-chain fatty acids (acetate, propionate and butyrate), alcohols, $\mathrm{H}_{2}$ and $\mathrm{CO}_{2}$, with $\mathrm{H}_{2}$ and $\mathrm{CO}_{2}$ being the main electron donors and acceptors, respectively. Methanogenic Archaea reduce some of these products (formate, acetate and $\mathrm{CO}_{2}$ ) with $\mathrm{H}_{2}$ to produce $\mathrm{CH}_{4}$ and water (JANSSEN, 2008; MORGAVI et al., 2010; HAMILTON et al., 2010).

The production of $\mathrm{CH}_{4}$ by enteric fermentation of ruminants generates gross energy losses of feeds, varying from $2 \%$ by animals feeding on high-grain diets, to $12 \%$ when low quality forage is fed (JOHNSON; JOHNSON, 1995; JOHNSON et al., 2007). However, the accumulation of $\mathrm{H}_{2}$ inhibits the enzymatic systems, mainly the processes involving nicotinamide adenosine diphosphate $\left(\mathrm{NADH}+\mathrm{H}^{+} \leftrightarrow \mathrm{NAD}^{+}\right.$) (MCALLISTER; NEWBOLD, 2008) and the regulation of ruminal $\mathrm{pH}$. Thus, there is a need to drain the $\mathrm{H}_{2}$ molecules produced for optimal rumen functioning, and the main means is the production of $\mathrm{CH}_{4}$.

The ruminal methane production is extremely dependent on the quantity and how the substrate is fermented. According to Johnson and Johnson (1995), grazing animals emit more methane than animals receiving diets with higher levels of concentrate. Animals that feed on larger amounts of forage will provide greater acetate production and consequent release of hydrogens that can be used for the formation of $\mathrm{CH}_{4}$. The production of methane is inversely related to propionate production and positively related to acetate production. 
In Brazil, most of the beef cattle production is based on grazing system. Thus, methane emissions are high; however, it could be reduced, with the supplementation of animals on pasture and adequate management of pastures.

\subsection{Animal production on pastures}

Pastures are the basis for feeding Brazilian herds. The majority of cattle in Brazil are born and remain in pasture until slaughtered, requiring high production and quality forage (BUSTAMANTE et al., 2012); however, the production of tropical forage is seasonal. Due to climatic variations during the year, there is a contrast between excess forage in the most favorable months from November to March (rainy season) and the scarcity of forage in the least favorable months from April to October (dry season) (SANTOS et al., 2009).

During the dry season, grasses may have crude protein contents below 7\%, considered as the minimum required for fibrinolytic activity of ruminal microbiota, and high lignification content, resulting in decreased voluntary intake and diet digestibility. These factors reduce animal performance and contribute to increase enteric methane emissions (ARCHIMEDE et al., 2011).

The grasses of the genus Urochloa accumulate from 77 to $90 \%$ of the total production of dry matter during the rainy period (PIZARRO et al., 1996). Consequently, pastures with these forages present high stocking rates in this period, which are drastically reduced during the dry season (EUCLIDES, 2000).

The highest percentage of dead material is found in the dry season. Several researchers report that the maximum consumption in pastures can be limited when the pasture has a high percentage of dead material, even when the availability of dry matter is elevated (EUCLIDES et al., 1990).

The cattle are selective, preferentially consuming the leaves, due to the ease of apprehension with less energy expenditure for the harvest in relation to the stems. The green leaves have less resistance to breakage by chewing, greater nutritional value and shorter retention time in the rumen, which directly interferes in the animal's performance (CARLOTO et al., 2011).

Animal performance is related to dry matter intake. To achieve high animal performance in areas with a high stocking rate, the herbage allowance must be provided from three to four times the animal ingestive capacity. In this sense, maximum levels of consumption and animal performance are related to the herbage allowance of 10 to $12 \%$ of body weight (HODGSON, 1990). Therefore, with this offer, there is a greater possibility of selecting the most nutritious fractions. 
The high herbage allowance is positively correlated with the increase in canopy height and the stem elongation rate, causing an increase in the percentage of dead material due to shading (CASAGRANDE et al., 2010; HERLING et al., 2011). The canopy height affects the distribution of light within the plant population and the circulation of air, altering the photosynthetic processes and leaf area (PARSONS et al., 1983).

Nutritional restrictions imposed on cattle raised on tropical pastures, especially in the dry season, require adjustment of supply with demand for nutrients. Strategies to overcome the deficiency are necessary in most livestock production systems. Corn or sorghum silage, hay, sugar cane, pasture fertilization and irrigation, and deferred pastures are among the options indicated to minimize the consequences of the dry season and improve the productivity of Brazilian livestock systems (SANTOS et al., 2009; MAGALHÃES et al., 2012; MOREIRA et al., 2013).

\subsection{Rotated pastures}

Essentially the grazing methods are associated with the process of harvesting the forage by the animals. According to Allen et al. (2011), "grazing method" is a procedure or technique for manipulating animals in space and time in order to reach a specific objective. The method allows you to control how, when, what and how much the animals graze. For Sollenberger et al. (2012), the stocking method refers to the way animals are stored or have access to pastures or paddocks (pasture subdivisions, if any), during grazing.

Rotated pastures consist of an area that is divided into paddocks that are subjected to alternating periods of grazing and resting. The great advantage of this method is to provide greater control over the pasture, allowing to define when and for how long the plants will be subject to defoliation. Thus, grazing tends to be more uniform and grazing efficiency higher (BALSALOBRE, 2004).

According to Costa (2015), rotated pasture is appropriate for intensifying the production of animal protein on pasture, in addition to being an ally in controlling the degradation of the area, ensuring sustainability in production, reducing the production of methane gas, providing significant increases in animal productivity, if effectively managed. Although some literatures contest the advantages of the rotated grazing method over the continuum, it is known that in the case of the upright growth plants, whose species present fast development in the meristems apical, the application of the rotated grazing method, facilitates the management of these pastures. 


\subsection{Deferred pastures}

Deferred pasture is a management strategy that consists of selecting a certain area of the property and excluding it from grazing, usually in late summer, with the aim of ensuring accumulation of forage to be used during the scarcity period of forage resource (SANTOS et al., 2009).

The most suitable forages for the forage stockpiling technique are those with a lower canopy height, thin stems, a high percentage of leaves than stems and excellent forage production. According to Fonseca and Santos (2009), preference should also be given to forage grasses, which do not show peak flowering in autumn, as tillers in the reproductive stage have lower nutritional value than those in the vegetative stage.

Plants of the genus Urochloa are characterized by being flexible to use and manage, being tolerant to a series of limitations and/or restrictive conditions of use for many forage species (DA SILVA, 2010). According to Santos and Bernardi (2005), the species Urochloa decumbens cv. Basilisk, Cynodon spp. and Urochloa brizantha cvs. Marandu and Piatã are good options for forage stockpiling.

The variation in the structure and morphological composition of the deferred forage must be understood, to increase the efficiency in the use of this grazing system. Changes in canopy height, forage mass, percentages of leaves, stems and dead material modify the quality of the forage, mainly due to the physiological maturity of the plants (SANTOS et al., 2008).

In winter, the percentage of green leaf decreases, and the percentage of stems and dead material increases in deferred pasture (SILVA et al., 2016). This change in the structure of the deferred pasture influences the selectivity of the animal, which starts to consume less green leaf and more stems and dead material (SANTOS et al., 2013), negatively influencing the quality of the diet ingested and animal performance. The moment of forage stockpiling is one of the aspects that most influence the structural and morphological characteristics of the pasture.

According to Nussio and Schimidt (2010), the forage stockpiling must be carried out at the end of the rainy season, when the soil moisture is not limiting the growth of the plants. Extending the pasture deferred to allow the use of the area by the animals at the end of the rainy season can negatively affect the accumulation of forage mass, due to the water deficit in the soil. The moment to differ the pastures depends on the climatic characteristics of each region, however, in general it 
recommends that it be carried out between December and April, and the use, between June and September (SANTOS; BERNARDI, 2005).

To accelerate the growth of the plant and, consequently, increase the rate of forage accumulation, it is necessary to apply nitrogen to the soil at the beginning of the forage stockpiling. Nitrogen fertilization is normally used during the period of greatest rainfall, in order to increase the production of forage per area. However, fertilization in late spring and early autumn, when the pasture forage stockpiling starts, brings benefits, providing an increase in the production of forage mass (SANTOS et al., 2009).

Several studies prove the possibility of obtaining reasonable forage mass and performance in deferred pasture. Silva et al. (2009) found a great variation in the production of forage mass in deferred pastures in Brazil, from 1,300 to $14,386 \mathrm{~kg} \mathrm{ha}^{-1}$, with an average of $6,431 \mathrm{~kg} \mathrm{ha}^{-1}$. The weight gain of animals kept on deferred pastures with supplementation varies from 0.490 to $0.725 \mathrm{~kg}$ per day (SILVA et al., 2016).

According to Fonseca et al. (2013) deferred pastures are characterized by stocking rates rarely exceeding 1.5 to $2.0 \mathrm{AU}^{-1}$ per year. However, considering an average stocking rate in Brazil of 0.6 $\mathrm{AU} \mathrm{ha}{ }^{-1}$, the deferred pasture is promising technology to increase the carrying capacity of pastures.

The animals kept on deferred pastures may perform modestly or simply maintain the body weight (SANTOS et al., 2004), as deferred forage is generally of low quality. Therefore, in order to improve animal performance, the supplementation strategy in deferred pasture can be adopted to complement the nutritional value of the available forage and/or improve feed conversion (EUCLIDES; MEDEIROS, 2005).

\subsection{Pasture cattle supplementation}

Tropical pastures are the main source of nutrients and energy for cattle in many countries. However, due to the tropical climate and the seasonality of tropical grasses, diets based only on pasture are frequently imbalanced. Consequently, feed intake, digestibility and animal productive performance are generally low (EUCLIDES et al., 2009).

Supplementation aims to complement the diet providing nutritional elements, such as energy, protein, minerals, and vitamins that are lacking or in insufficient quantities to meet the animal requirements (TEIXEIRA et al., 2019; WASSIE et al., 2019). 
Nitrogen and/or energy supplementation improves the digestibility of nutrients. The presence of the supplement in the diet provides necessary substrates for the rumen microorganisms, favoring the increase of fibrolytic bacteria and degradation capacity fiber (MARQUEZ et al., 2014).

The supplements are used to increase the animal performance, both in the dry and rainy period, and these are defined by the level of protein and total digestible nutrients (TDN), which must be greater than or equal to $15 \%$ and $60 \%$, respectively (FRANCO et al., 2007).

Urea is the main source of non-protein nitrogen (NNP) supplied to ruminants. However, other unconventional sources of NNP, which have a greater reduction in GHG emissions, are being evaluated for commercial use (RICHARDSON et al., 2019).

\subsection{Nitrate supplementation}

The use of nitrate in ruminant diets has received attention, being a promising agent in the mitigation of $\mathrm{CH}_{4}$. Several studies have shown satisfactory results of the inclusion of nitrate in the diet, which provides a reduction in the production of $\mathrm{CH}_{4}$ (NOLAN et al., 2010; NEWBOLD et al. 2014; VELAZCO et al., 2014; VILLAR et al., 2020). The transformation of nitrate into ammonia by ruminal microorganisms is highly competitive with the $\mathrm{CH}_{4}$ producing route, consuming eight $\mathrm{H}_{2}$ electrons, reducing methanogenic microorganisms, due to the lower availability of electrons or the toxicity of nitrite to these microorganisms (VAN ZIJDERVELD et al., 2010; HULSHOF et al., 2012).

In addition to being a useful source of non-protein nitrogen (NPN) for ruminants as a urea substitute (VAN ZIJDERVELD et al. 2011; HULSHOF et al. 2012; LI et al. 2012), nitrate also provides ammonia for microbial protein synthesis in the rumen (LENG, 2008). Microbial protein has a high biological value and represents up to $80 \%$ of the protein absorbed in the intestine $(\mathrm{BACH}$ et al., 2005), therefore, the increase in microbial protein synthesis has a positive impact on the animal performance.

Despite presenting beneficial effects, in Brazil nitrate is commercialized as fertilizer. There is still no commercial form for nitrate animal feed, due mainly to its potential toxicity. The concern is due to the fact that nitrate is initially converted to nitrite and later to ammonia within the rumen. When the reduction of nitrite exceeds the conversion of nitrite to ammonia, the nitrite is absorbed by the rumen wall and reaches the bloodstream, which may lead to oxidation of hemoglobin to methemoglobin. High levels of methemoglobin prevent oxygen transport (LEE; BEAUCHEMIN, 2014), leading the animal to death (MCALLISTER et al., 1996). However, a 15-day gradual adaptation period is an alternative way to reduce the risk of toxicity (ALEMU et al., 2019). 
Several in vivo studies confirmed the efficacy of feeding nitrate on reducing enteric methane emissions without resulting in clinical signs of toxicities (NOLAN et al., 2010; VAN ZIJDERVELD et al., 2011; LI et al., 2012).

In a study conducted by Cassiano et al. (2017), different levels of calcium nitrate inclusion ( 0 , 1, 2 and 3\% in DM) were tested in the diet of Nellore and Holstein females, and no clinical effects of intoxication by the addition of nitrate were shown. Van Zijderveld et al. (2011), in a study with dairy cows fed diets containing $8.8 \%$ calcium nitrate of dietary DM per 90 days, found a persistent reduction in methane emissions up to $16.5 \%$, and no clinical effects of intoxication. Nolan et al. (2010) observed a reduction of $23 \%$ when included $4 \%$ of potassium nitrate in the diet.

Among the expected effects with the use of nitrate are the reduction of propionate production, increasing the concentration of acetate, since nitrate is a more efficient $\mathrm{H}_{2}$ acceptor than propionate (UNGERFELD; KOHN, 2006), increase in ruminal pH (LEE et al., 2015a), reduce dry matter intake (HULSHOF et al., 2012). Nitrate tastes bitter, which lowers palatability of nitrate-based diets causing lower feed intake (LEE et al., 2014).

In vivo studies evaluating the effects of ammonium nitrate on the mitigation potential of enteric methane and on performance when added to pasture cattle supplementation are scarce.

\section{MATERIAL AND METHODS}

\subsection{Location}

The experiment was carried out at College of Veterinary Medicine and Animal Science (FMVZ/USP), Pirassununga, Sao Paulo State, Brazil. The climate is classified as subtropical, with an average annual rainfall of $1,300 \mathrm{~mm}$ and an average temperature of $23^{\circ} \mathrm{C}$. The soil is the Dystroferric Dark Red Latosol type (EMBRAPA, 1999).

The experimental area had 14.4 ha divided into 8 experimental units, 4 of these areas were subdivided in 6 paddocks with 0.3 ha each one (rotated areas) and other 4 modules (deferred grazing areas) with 1.8 ha each one (Figure 1). The area was established with Urochloa Brizantha cv. Marandu. All experimental units had autofill drinkers and fixed feeders for daily fresh water and supplementation supply, respectively. 
Figure 1. Image: Aerial view of the experimental area.

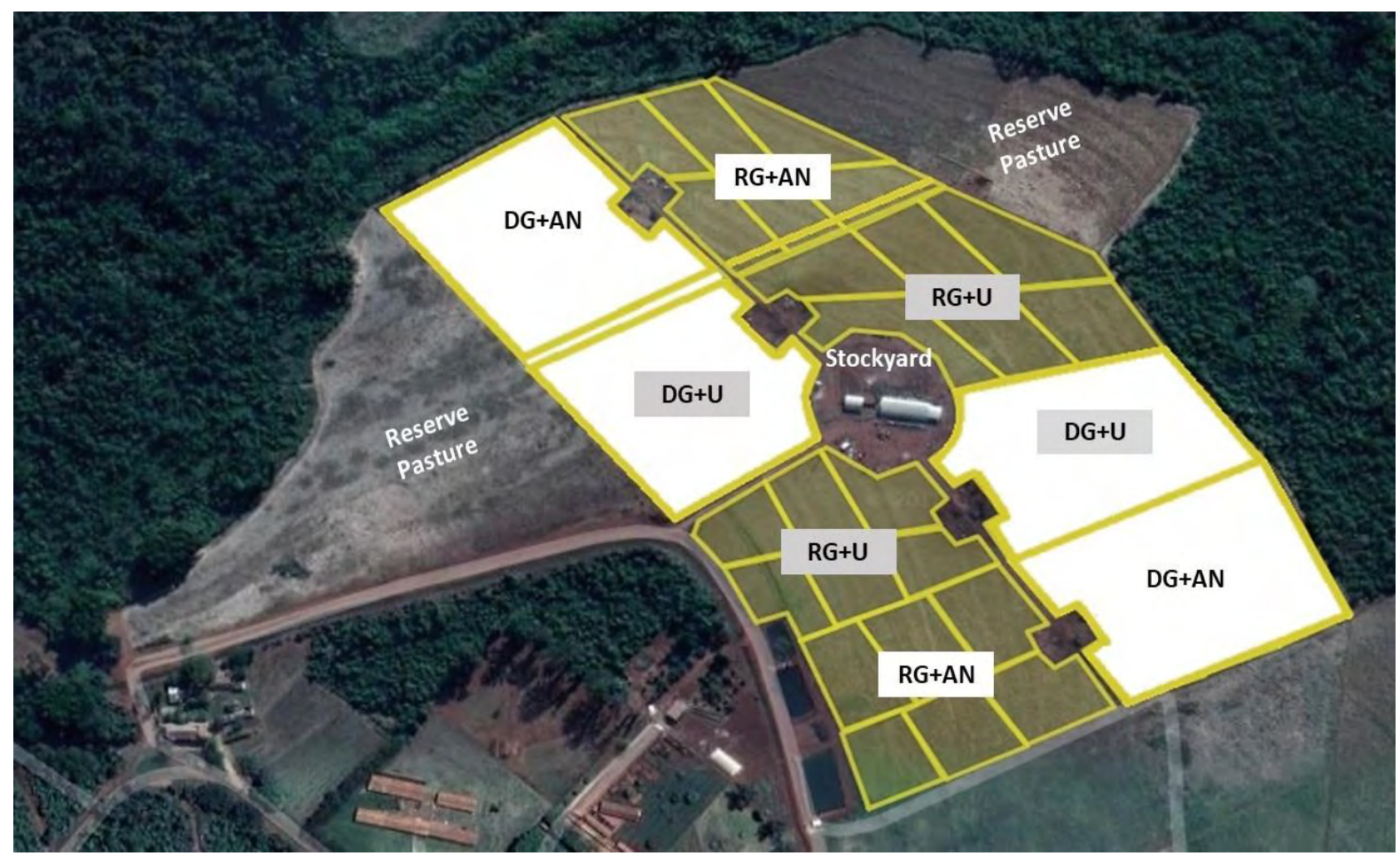

Source: Google maps.

\subsection{Climate data}

The climatic data, precipitation $(\mathrm{mm})$ and average monthly temperature (Figure 2), were collected at the weather station located on the University Campus and a few meters from the experimental area. The station is programmed to record the climatic data every 10 minutes, during the entire experimental period, the data were available on the official website of the Campus. 
Figure 2. Graphic with climatic data during the trial period.

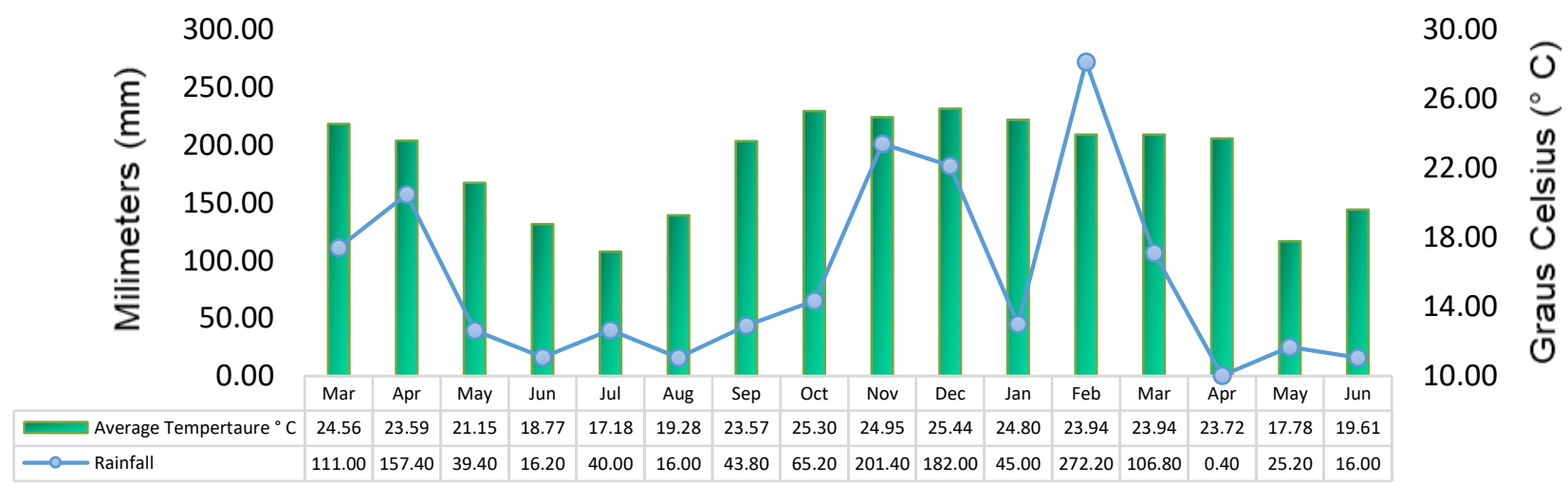

Source: Own authorship.

\subsection{Experimental period}

The experiment lasted 2 consecutive years, with the second year repeating the first, but in this work the data of the first year of the experiment were presented. The experiment began on June 18, 2019 and finished on June 19, 2020. Sampling was done in each season (spring, summer, autumn and winter) during 1 year.

\subsection{Experimental design, treatments, and pastures}

The experimental units consist of 8 modules. Each treatment was allotted to 2 modules in a randomized block design (blocks were formed as a function of terrain location), as shown in the Figure 1 . The treatments consisted of two grazing methods and two nitrogen sources $(2 \times 2$ factorial arrangement):

1) Deferred grazing plus urea supplementation (DG+U);

2) Deferred grazing plus ammonium nitrate supplementation (DG+AN);

3) Rotated grazing plus urea supplementation $(\mathrm{RG}+\mathrm{U})$; and

4) Rotated grazing plus ammonium nitrate supplementation (RG+AN).

\subsection{Animals and ethical issue}

The experiment followed the guidelines established in accordance with the ethical principles 
of animal experimentation by the Animal Use Ethics Committee (CEUA) of the College of Animal Science and Food Engineering - University of Sao Paulo (FZEA-USP), under the protocol number 5360270819 . A total of 24 Nellore heifers of initial average body weight $350 \mathrm{~kg}( \pm 53 \mathrm{~kg}$ ) and with 15-17 months old were used as experimental animals. The experimental animals called tracers were randomly allotted to 8 experimental units, each received 3 animals ( 6 animals per treatment). Animals called regulators were used to adjust the stocking rate, using the "put and take" technique (Mott and Lucas, 1952) in each experimental area; however, these animals were be evaluated in the experiment, were only accounted for in the stocking rate.

\subsection{Supplementation}

The supplements were formulated using the Microsoft Excel, where the chemical composition of the ingredients was estimated according to the NRC (2016). Ammonium nitrate and urea were supplied as a non-protein nitrogen source, formulated for 0.2 and $0.1 \%$ of BW intake, for rainy and dry season, respectively, available ad libitum for all animals. The animals received 7 days of the adaptation supplement; after adaptation, supplements were formulated according to the season (rainy or dry) during the sampling periods, as shown in Table 1.

Table 1. Proportion of supplement ingredients.

\begin{tabular}{|c|c|c|c|c|c|c|c|}
\hline \multirow{3}{*}{\multicolumn{2}{|c|}{ Ingredients (\%) }} & \multicolumn{6}{|c|}{ Supplementation } \\
\hline & & \multicolumn{2}{|c|}{ Adaptation } & \multicolumn{2}{|c|}{ Dry Season } & \multicolumn{2}{|c|}{ Rainy Season } \\
\hline & & Urea & Nitrate & Urea & Nitrate & Urea & Nitrate \\
\hline \multicolumn{2}{|c|}{ Ground corn } & 55 & 55 & 48 & 45 & 72 & 69 \\
\hline \multicolumn{2}{|c|}{ White salt } & 20 & 15 & 15 & 10 & 7 & 5 \\
\hline \multicolumn{2}{|c|}{ Mineral mixture $^{1}$} & 15 & 15 & 15 & 15 & 8 & 8 \\
\hline \multicolumn{2}{|c|}{ Urea } & 10 & - & 22 & - & 13 & - \\
\hline \multirow{2}{*}{\multicolumn{2}{|c|}{ Ammonium nitrate }} & - & 15 & - & 30 & - & 18 \\
\hline & & \multicolumn{6}{|c|}{ Estimated Chemical Composition } \\
\hline $\mathrm{CP}$ & $(\%)$ & 33.05 & 35.89 & 66.14 & 65.93 & 43.01 & 43.34 \\
\hline TDN & $(\%)$ & 48.40 & 48.40 & 42.24 & 39.60 & 63.36 & 60.72 \\
\hline NPN & $(\%)$ & 3.65 & 5.40 & 8.03 & 10.80 & 4.75 & 6.45 \\
\hline $\mathrm{CF}$ & $(\%)$ & 1.27 & 1.27 & 1.10 & 1.04 & 1.66 & 1.59 \\
\hline EE & $(\%)$ & 1.60 & 1.60 & 1.39 & 1.31 & 2.09 & 2.00 \\
\hline NDF & $(\%)$ & 4.35 & 4.35 & 3.79 & 3.56 & 5.69 & 5.45 \\
\hline ADF & $(\%)$ & 1.43 & 1.43 & 1.25 & 1.17 & 1.87 & 1.79 \\
\hline
\end{tabular}

CP: Crude Protein; TDN: Total Digestive Nutrients; NPN: Non-Protein Nitrogen; CF: Crude Fiber; EE: Ether Extract; NDF: Neutral Detergent Fiber; ADF: Acid Detergent Fiber; ${ }^{1}$ Mineral mixture, quantity per kg of product: $200 \mathrm{~g}$ of calcium, $160 \mathrm{~g}$ of phosphorus, $60 \mathrm{~g}$ of sulfur, $185 \mathrm{~g}$ of sodium, $200 \mathrm{mg}$ of cobalt, $2.5 \mathrm{~g}$ of copper, $1.6 \mathrm{~g}$ of fluorine, 125 $\mathrm{mg}$ of iodine, $2.25 \mathrm{~g}$ of manganese, $50 \mathrm{mg}$ of selenium, $7.5 \mathrm{~g}$ of zinc. (Own authorship).

\subsection{Soil preparation}

Average chemical characteristics of the soil were: $\mathrm{pH}\left(\mathrm{CaCl}_{2}\right) 5.8$; Presin $\left(\mathrm{mg} \mathrm{dm}^{-3}\right) 30.5$; $\mathrm{MO}$ $\left(\mathrm{g} \mathrm{dm}^{-3}\right)$ 33.1; $\mathrm{S}\left(\mathrm{mg} \mathrm{dm}^{-3}\right)$ 7.1; $\mathrm{K}\left(\mathrm{mmolc} \mathrm{dm}^{-3}\right)$ 4.7; $\left.\mathrm{Ca}\left(\mathrm{mmolc} \mathrm{dm}^{-3}\right) 44.5 ; \mathrm{Mg}_{(\mathrm{mmolc} \mathrm{dm}}{ }^{-3}\right)$ 21.9; 
$\mathrm{H}+\mathrm{Al}\left(\mathrm{mmolc} \mathrm{dm}^{-3}\right)$ 23; CTC (mmolc dm $\left.{ }^{-3}\right)$ 94.3; SB (mmolc dm $\left.{ }^{-3}\right) 71.3 ; \mathrm{V}(\%) 75.4 ; \mathrm{B}\left(\mathrm{mg} \mathrm{dm}^{-3}\right)$ 0.6; $\mathrm{Cu}\left(\mathrm{mg} \mathrm{dm}^{-3}\right)$ 1.8; Fe $\left(\mathrm{mg} \mathrm{dm}^{-3}\right)$ 25.4; $\mathrm{Mn}\left(\mathrm{mg} \mathrm{dm}^{-3}\right) 4.3 ; \mathrm{Zn}\left(\mathrm{mg} \mathrm{dm}^{-3}\right) 1.2$.

In November of 2018, previously the beginning of the experiment, liming was carried out using $1900 \mathrm{~kg}$ of dolomitic limestone per hectare. In January of 2019, the pastures were fertilized with $50 \mathrm{~kg} \mathrm{ha}^{-1}$ of nitrogen and $50 \mathrm{~kg} \mathrm{ha}^{-1}$ of potassium, and the 20-00-20 $\left(\mathrm{N}-\mathrm{P}_{2} \mathrm{O}_{5}-\mathrm{K}_{2} \mathrm{O}\right)$ fertilizer was used. In November of 2019, the pastures were fertilized with $53 \mathrm{~kg} \mathrm{ha}^{-1}$ of nitrogen and $57.5 \mathrm{~kg}$ $\mathrm{ha}^{-1}$ of sulfur, using ammonium sulfate fertilizer. In January and March of 2020, the ammonium nitrate fertilizer was used, being $56.7 \mathrm{~kg} \mathrm{ha}^{-1}$ of nitrogen in each application. Fertilizations were carried out weekly post-grazing in rotated paddocks, and in deferred pastures it was carried out in just one day, on the same day when the last paddock of the rotated pastures was fertilized. Total area fertilization was performed using a centrifugal distributor with disc, and gravimetric dosing coupled to the tractor.

\subsection{Grazing methods and herbage allowance}

The pastures were deferred on March 25, 2019, on average with $30 \mathrm{~cm}$ of canopy height. The pastures were closed and left without grazing for 84 days, ending on June 18, 2019.

The rotated area was divided into 6 paddocks of 0.3 hectares each, with a fixed grazing period of 7 days and 35 days of rest. The average herbage allowance (HA) was $12.76 \%$ average in winter, $10.08 \%$ in spring, $9.57 \%$ in summer, and $6.01 \%$ of body weight in autumn. The calculations followed the method suggested by Sollenberger (2005) according to eq.(1). The HA did not consider the accumulation of forage that occurred during the seven days of grazing.

$$
\mathrm{HAR}=\left(\frac{\text { Forage mass }}{\text { Period }}\right) *\left(\frac{\text { Paddock area }}{\mathrm{BW}}\right)
$$

The deferred area had 1.8 hectares and continuous grazing method was adopted. The HA was $12.85 \%$ in winter, $6.94 \%$ in spring, and $4.42 \%$ of body weight in summer, according to eq.(2).

$$
\mathrm{HAD}=\text { Forage mass } *\left(\frac{\text { Paddock area }}{\mathrm{BW}}\right)
$$

Where: HAR = Herbage allowance in the rotated pastures ( $\mathrm{kg}$ of forage to $100 \mathrm{~kg} \mathrm{BW}^{-1}$ per day); $\mathrm{HAD}=$ Herbage allowance in the deferred pastures $\left(\mathrm{kg}\right.$ of forage to $100 \mathrm{~kg} \mathrm{BW}^{-1}$ ); Forage Mass $=$ Dry forage mass $\left(\mathrm{kg} \mathrm{ha}^{-1}\right)$; 
Period $=$ Days in grazing period;

Paddock Area $=$ experimental unit area $\left(\mathrm{ha}^{-1}\right)$;

$\mathrm{BW}=$ Total body weight of animals in the paddock $(\mathrm{kg})$.

\subsection{Stocking rate}

The stocking rate (SR) was adjusted according to each forage sampling, and weighing of the animals, in order to maintain the herbage allowance in the percentages that have been fixed for each season. The SR was expressed in animal unit (AU), assuming that one AU is equivalent to $450 \mathrm{~kg}$ for animals of the Zebu breed, according to eq.(3).

$$
\mathrm{SR}=\left(\frac{\mathrm{BWtotal}}{\mathrm{AU}}\right) / \text { Area }
$$

Where: $\mathrm{SR}=$ Stocking rate $\left(\mathrm{AU} \mathrm{ha}{ }^{-1}\right) ; \mathrm{BW}_{\text {total }}=$ Total body weight of tracers and regulators animals present in the experimental area $(\mathrm{kg}) ; \mathrm{AU}=$ Animal unit $(450 \mathrm{~kg})$; Area = Experimental unit area $\left(\mathrm{ha}^{-}\right.$ $\left.{ }^{1}\right)$.

\subsection{Procedures for sampling, evaluation, and nutritional value of forage}

\subsubsection{Characterization of pasture productive components}

For characterization of pasture productive components, forage samples were collected from each experimental unit (deferred pasture or paddocks depending on the experimental units).

For pre-grazing, two representative paddocks of each rotated module were chosen to collect the forage. Sampling was performed every 42 days for each paddocks of the module, using a $0.25 \mathrm{~m}^{2}$ metallic structure that was randomly thrown in the paddock, avoiding places with feces. After the launch of the square, the canopy height was measured, with the support of a 1-meter ruler graduated in $\mathrm{cm}$, and then all the forage contained inside was harvested at ground level, manually with pruning shears. This procedure was repeated 4 times in each paddock, totaling 4 samples per paddock, each sample was separated into 2 subsamples. The first subsample was for determination of dry forage mass at the paddock. The second subsample was used for determination of morphological composition. Both samples were conditioned in paper bag and dried in forced air circulation oven at $65^{\circ} \mathrm{C}$ during 72 hours, after drying, the paper bags were weighed on a precision scale and used for chemical analysis. The total available of forage mass per hectare was estimated using the equation: 
$\mathrm{TADFM}=(\mathrm{AS} * \mathrm{HA}) / \mathrm{MFA}$

Where: TDFM = Total Available of Dry forage mass $\left(\mathrm{kg} \mathrm{ha}^{-1}\right)$; AS = Average of the 4 samples $(\mathrm{kg})$; $\mathrm{HA}=1$ hectare $\left(\mathrm{m}^{2}\right) ;$ MFA $=$ Metallic frame area $\left(\mathrm{m}^{2}\right)$.

The sampling of post-grazing was performed in the same way as described for pre-grazing; however, the samples were dried in forced air circulation oven at $65^{\circ} \mathrm{C}$ during 72 hours, to determine the dry forage mass and then were discarded.

During the forage stockpiling phase, sampling was carried out every 21 days, following the same way as described for rotated pre-grazing. After the animals entered the deferred pastures, extrusion cages were used. Four extrusion cages were randomly distributed in each deferred module, avoiding places with feces. Every 21 days the cages were changed places. After removing the cages, the $0.25 \mathrm{~m}^{2}$ metallic structure was placed in place, the canopy height was measured, and then all the forage contained inside was harvested at ground level, manually with pruning shears. A total of 4 samples per paddock were collected, each sample was separated into 2 subsamples. The first subsample was for determination of dry forage mass. The second subsample was used for determination of morphological composition. Both samples were conditioned in paper bags and dried in forced air circulation oven at $65^{\circ} \mathrm{C}$ during 72 hours. After drying, the paper bags were weighed on a precision scale and used to determine the chemical composition. The total available of forage mass per hectare was estimated using the eq.(4).

Around each extrusion cage present in the paddock, forage collection was carried out using the metallic frame, in the same way as described for post-grazing in rotated. This collection was performed on the same day that the extrusion cages collections. The total available of forage mass per hectare was estimated using the eq.(4).

\subsubsection{Forage morphological composition}

Morphological composition in a sub-sample was done by separation and determination of the proportion of morphological components as: green leaf blades, green stems (true stems plus leaf sheaths), and dead material. Dead material was visually defined as senescent leaves and stems with $\geq 50 \%$ area of yellow or dry tissue. After separated, the components were conditioned in paper bags and dried in forced air circulation oven at $65^{\circ} \mathrm{C}$ for 72 hours. After drying, the paper bags were weighed on a precision scale. Then, the percentage proportion of each component was calculated. 


\subsubsection{Forage chemical composition}

For the chemical characterization of dry forage samples were ground into Willey type mill using $1 \mathrm{~mm}$ mesh screen, and the samples were composed by season. This sample was used to determine crude fiber $(\mathrm{CF})$, mineral matter $(\mathrm{MM})$, crude protein $(\mathrm{CP})$, ether extract $(\mathrm{EE})$, lignin, acid detergent fiber (ADF), neutral detergent fiber (NDF) and in vitro digestibility of organic matter (IVDMD). Near Infrared Reflectance Spectroscopy (NIRS) was used, according to Marten et al. (1984). The reflectance data of the samples, in the wavelength range from 1,100 to $2,500 \eta \mathrm{m}$, were stored by a model NR5000 spectrometer coupled to a microcomputer.

\subsubsection{Accumulation rate}

The rate of dry matter accumulation per cycle was determined by combining production and residue data. Cumulative dry mass $\left(\mathrm{kg} \mathrm{ha}^{-1}\right)$ of forage was obtained by the difference between the forage dry mass of the sample taken inside the cage or from pre-grazing (depending on the grazing method) on the date of sampling and the forage dry mass of the sample outside the cage (metallic frame) or from post-grazing (depending on the grazing method) on the date of the previous sampling. The daily accumulation rate $\left(\mathrm{kg} \mathrm{ha}^{-1}\right)$ of forage was calculated by dividing the cumulative forage dry mass in each period sampled by the number of days between evaluations.

\subsection{Procedures for assessing animal responses}

\subsubsection{Animal performance}

Animals were weighed at the beginning of the experiment and subsequently at regular intervals of 28 days, using digital scale with $0.1 \mathrm{~kg}$ accuracy. In the first and last weighing of the experiment, the animals were weighed after 12 hours of fasting. The individual performance was evaluated by animals average daily gain (ADG) obtained by dividing the body weight (BW) difference between two successive weighing by the interval of days between measurements, according to the eq.(5).

$$
\mathrm{ADG}=(\mathrm{fBW}-\mathrm{iBW}) / \mathrm{IW}
$$

Where: $\mathrm{ADG}=$ Average daily gain $(\mathrm{kg})$; $\mathrm{fBW}=$ final $\mathrm{BW}$, most recent animal weight $(\mathrm{kg}) ; \mathrm{BW}=$ initial BW, animal weight from previous weighing $(\mathrm{kg})$; IW = Interval between weighing (days).

\subsubsection{Hand-plucking or grazing simulation}


The grazing simulation was carried out once each year season, totaling 4 samples per year. Pasture was sampled manually, simulating the forage consumed by the animals. Sampling was carried out in 3 days, when the animal enters the rotated paddock, on the $4^{\text {th }}$ day of grazing, and on the last day of grazing. The same days were used for deferred pastures. For the sampling to be similar to the forage consumed by the animals, the heifers destined for consumption were observed for a few minutes and followed during grazing. In this way, the material was collected in places close to those selected by the observed animal, and for greater similarity some requirements are followed: the quantity sampled in each point is similar to the quantity harvested by the animal; the proportion of leaves, stem and dead material in the sample was visually similar to the proportion harvested by the animal; the length of the leaves that was removed by sampling, was similar to that removed by grazing. Each experimental unit had a sample composed of 3 days of sampling. The samples were dried in forced air circulation oven at $65^{\circ} \mathrm{C}$ during 72 hours and ground into Willey type mill using 1 and $2 \mathrm{~mm}$ mesh screen to determine the chemical composition and for iNDF analysis, respectively.

\subsubsection{Forage intake}

Two heifers from each treatment were used to measure consumption. The sampling period was carried out in the middle of each season of the year, totaling 4 samplings during 1 year. To estimate forage intake, titanium dioxide powder $\left(\mathrm{TiO}_{2}\right)$ was being used as an external indicator of fecal production, and the indigestible neutral detergent fiber (iNDF) as an internal indicator to determine forage digestibility. For the supply of $\mathrm{TiO}_{2}$, the heifers are taken to the stockyard, and the dosage method was manual, $15 \mathrm{~g}$ of $\mathrm{TiO}_{2}$ was supplied wrapped in paper deposited directly in the oral cavity of each heifer daily, at 8 a.m. The dosing period was 10 days and from the $5^{\text {th }}$ day onwards, feces were collected directly from the animal's rectum at the same time that $\mathrm{TiO}_{2}$ was supplied, except on the last day, which was collected only feces. The collected feces were stored in a freezer (at $20^{\circ} \mathrm{C}$ ); subsequently the samples were thawed, dried in forced air circulation oven at $65^{\circ} \mathrm{C}$ during 96 hours and ground into Willey type mill using $2 \mathrm{~mm}$ mesh screen, to determine the concentration of $\mathrm{TiO}_{2}$ and chromium oxide in dry feces, through atomic absorption spectrophotometry technique described by Myers et al. (2004), and that sample will also be used for iNDF analysis.

\subsubsection{Supplement intake}

During the same period of administration of $\mathrm{TiO}_{2}$, chromium oxide $\left(\mathrm{Cr}_{2} \mathrm{O}_{3}\right)$ was also administered mixed with the supplement, in proportion of 10 and $7.5 \%$, in the dry season and in the rainy season, respectively. To estimate supplement intake, the $\mathrm{Cr}_{2} \mathrm{O}_{3}$ was used as an external indicator 
of fecal production. Chromium oxide was determined following the methodology described by Almeida et al. (2007) by means of the energy dispersive X-ray fluorescence (EDXRF) technique.

\subsubsection{Indigestible neutral detergent fiber (iNDF)}

The internal marker iNDF was used to determine the digestibility of feeds. The samples of forage (from hand-plucking), feces and supplements were placed in $100 \mathrm{~g} / \mathrm{m}^{2}$ TNT filter bags and incubated for 288 hours in rumen of cannulated animals consuming pasture. After removing the TNT bags from the rumen, it was washed in a stream until completely cleared and were subsequently dried in forced air circulation oven at $65^{\circ} \mathrm{C}$ for 72 hours, to determine the NDF, according to the method described by Van Soest et al. (1991). The remaining residue was considered as iNDF content.

The final indigestibility of the feed was determined by the iNDF of the feed divided by the iNDF of the animal's feces.

Total daily fecal production is determined using the equation below:

$$
\mathrm{TDFP}=\left(\frac{\text { Indicator provided }}{\text { Indicator in the feces }}\right)
$$

Where: TDFP $=$ Total daily fecal production $(\mathrm{kg})$; Indicator provided $=(\mathrm{kg})$; Indicator in the feces $=$ $(\mathrm{kg})$.

The dry matter intake of the forage is determined by the following equation:

$$
\mathrm{DMI}=\left(\frac{\text { TDFP } * \text { Indigestibility of the feces }}{\text { Indigestibility of the feed }}\right)
$$

Where: DMI = Dry matter intake $\left(\mathrm{kg} \mathrm{day}^{-1}\right)$; Indigestibility of the feces $=(\%)$; Indigestibility of the feed $=(\%)$.

The dry matter intake of the supplement is determined by the following equation:

$$
\mathrm{DMI}=\left(\frac{\text { TDFP } * \text { Indicator of the feces }}{\text { Indicator ptovided }}\right)
$$

\subsubsection{Ruminal methane measurements}

Sulfur hexafluoride $\left(\mathrm{SF}_{6}\right)$ tracer gas was used as the method for measuring eructated $\mathrm{CH}_{4}$ (Johnson et al., 1994; adapted to Brazil by Primavesi et al., 2004). A small brass permeation tube, with a known $\mathrm{SF}_{6}$ permeation rate, was placed in the reticulum, orally at the beginning of the experiment, to allow the tracer gas to equilibrate in the rumen. The $\mathrm{CH}_{4}$ expelled through the animal's 
nostrils and mouth was captured by means of a silicone tube, transported by a capillary tube and deposited in a storage-collector, called canister (PVC tube, closed and molded to fit the neck of the animal), coupled to a halter. For each experimental unit, 2 heifers are used. Each animal went through a period of 5 days of adaptation to the use of the equipment (halter and canister), before the sampling period. The sampling was carried out once a season (winter-July; spring-October; summer-January; autumn-April. For 5 consecutive days, the animals were taken to the stockyard, at 8 a.m., respecting the same order of animals, avoiding large differences in collection times from one day to the next, ensuring 24 hours of gas collection. If the canister of any animal was broken or there was a problem with the capillary gas collector, it was replaced and the collection was extended for one more day, until the completion of the five recommended collections. Every day of the sampling, two systems of capillary tubes coupled to a canister were prepared, placed on the fences, to collect the gas present in the environment. These canisters containing the basal $\mathrm{CH}_{4}$ concentration of the environment were called blank.

At each sampling period (season), the samples were sent to Embrapa Meio Ambiente, in Jaguariuna, SP, Brazil and analyzed using a gas chromatograph (Agilent HP-6890, Delaware, USA; and Shimadzu GC-2014, Columbia, MD, USA). The $\mathrm{CH}_{4}$ flux was calculated according to Westberg et al. (1998), using the following equation:

$$
\mathrm{QCH}_{4}=\mathrm{QSF}_{6}\left[\left(\mathrm{CH}_{4}\right) \mathrm{y}-\left(\mathrm{CH}_{4}\right) \mathrm{b}\right] /\left[\left(\mathrm{SF}_{6}\right) \mathrm{y}-\left(\mathrm{SF}_{6}\right) \mathrm{b}\right]
$$

Where: $\mathrm{QCH}_{4}=\mathrm{CH}_{4}$ emission rate by animal; $\mathrm{QSF}_{6}=$ known $\mathrm{SF}_{6}$ emission rate from the capsule in the rumen; $\left(\mathrm{CH}_{4}\right) \mathrm{y}=\mathrm{CH}_{4}$ concentrations in the collection apparatus; $\left(\mathrm{CH}_{4}\right) \mathrm{b}=$ basal $\mathrm{CH}_{4}$ concentration; $\left(\mathrm{SF}_{6}\right) \mathrm{y}=\mathrm{SF}_{6}$ concentration in the collection apparatus and $\left(\mathrm{SF}_{6}\right) \mathrm{b}=$ basal $\mathrm{SF}_{6}$ concentration in the surrounding air. Data from this sampling is being used to calculate methane per hectare.

The scheme of all sampling carried out in each season of the year was shown in Figure 3. 
Figure 3. Scheme of the sampling period for each season.

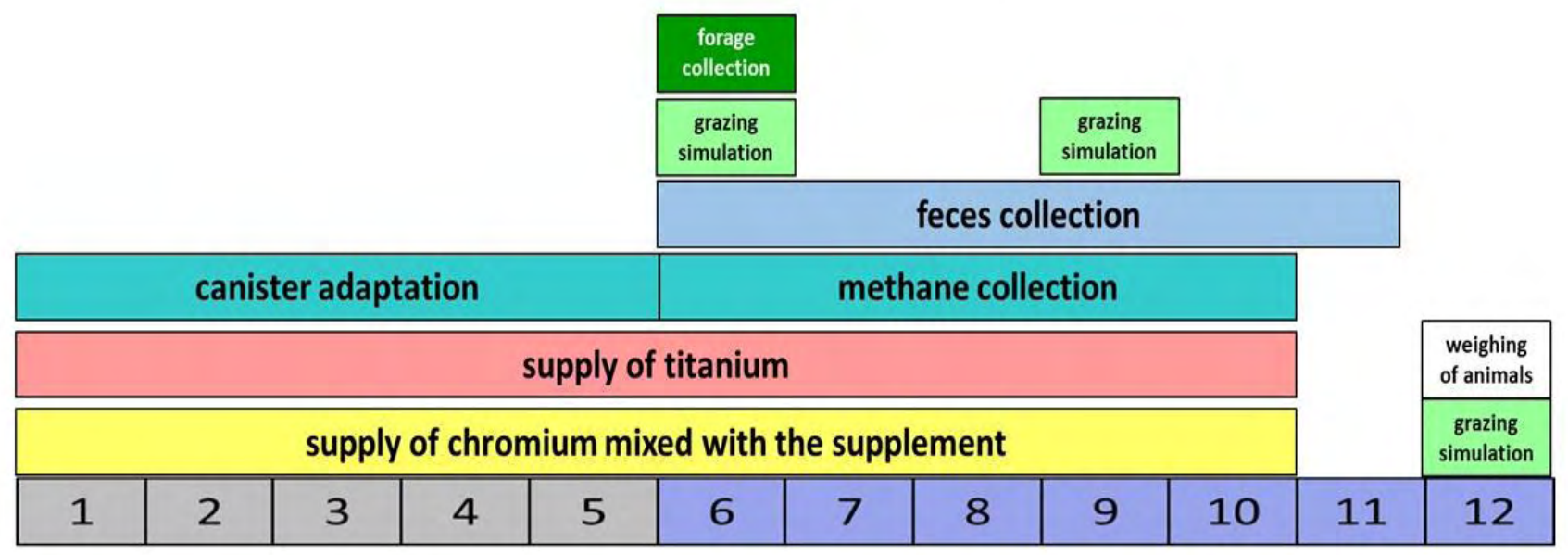

Days of Adaptation

Days of Sampling

Source: Own authorship.

\section{STATISTICAL ANALYSES}

Data were statistically analysed using the SAS 9.3 (SAS INSTITUTE INC., CARY, NC, USA). Before the actual analysis, the data were analysed for the presence of disparate information ("outliers") and normality of residuals (Shapiro-Wilk). When the normality assumption is not accepted, the logarithmic or the square root transformation was tested. Data were analysed according to the mixed procedure (PROC MIXED), and season was considered as repeated variable (split-plot in time), except for data collected during forage stockpiling. Among the 15 different covariance structures tested, the chosen one was based on the lower value of Corrected Akaike Information Criterion (AICC) (WANG; GOONEWARDENE, 2004). The model included the effects of grazing, nitrogen source and season as fixed factors. The effects of block (replicate area) were considered as random factors. In the presence of fixed effects interaction, effects of one factor inside the other was evaluated using the SLICE command of Mixed Procedure. All means were presented as least squares means and the treatment effects were separated by the PDIFF option of SAS. Effects were considered significant at $\mathrm{P} \leq 0.05$. 


\section{RESULTS}

Productive, morphological, and chemical components of Urochloa brizantha cv. Marandu during the forage stockpiling

Data with the productive, morphological, and nutritional value of Urochloa brizantha cv. Marandu in the forage stockpiling phase were shown in Table 2.

During the forage stockpiling phase, 4 evaluations were carried out every 21 days. The forage stockpiling was a pre-experimental phase, and the deferred pastures were sealed with an average initial canopy height of $30 \mathrm{~cm}$ and were not grazed for 84 days.

The total available of dry forage mass was increasing during the evaluations as shown in the Table 2. In evaluation 2 the available forage mass was higher than evaluation 1 (6276.02 vs. 3645.52 $\mathrm{kg} \mathrm{ha}^{-1}$ ), and evaluations 2 and 3, 3 and 4 were statistically equal.

The percentage of stems increased gradually during the evaluations. High percentage of stems (42.77) was noted with 84 days of forage stockpiling and lower percentage with 21 days (27.64).

The deferred pasture at 21 days showed higher content of ether extract (2.33\%) and lower $(0.52 \%)$ at 84 days. 
Table 2. Productive, morphological, and nutritional value of Urochloa brizantha cv. Marandu during the forage stockpiling phase.

\begin{tabular}{|c|c|c|c|c|c|c|}
\hline \multirow{3}{*}{ Variables } & $\begin{array}{c}\text { Evaluation } \\
1\end{array}$ & $\begin{array}{c}\text { Evaluation } \\
2 \\
\end{array}$ & $\begin{array}{c}\text { Evaluation } \\
\mathbf{3} \\
\end{array}$ & $\begin{array}{c}\text { Evaluation } \\
4\end{array}$ & \multirow{3}{*}{ SEM } & \multirow{3}{*}{$P$-value } \\
\hline & \multicolumn{4}{|c|}{ Forage Stockpiling (days) } & & \\
\hline & 21 & 42 & 63 & 84 & & \\
\hline TADFM $\left(\mathrm{kg} \mathrm{ha}^{-1}\right)$ & $3645.52^{\mathrm{c}}$ & $6276.02^{b}$ & $7165.27^{\mathrm{ab}}$ & $8890.77^{\mathrm{a}}$ & 599.42 & 0.0012 \\
\hline $\mathrm{ACH}(\mathbf{c m})$ & 35.00 & 37.50 & 57.30 & 68.60 & 4.77 & 0.0784 \\
\hline Leaf $(\%)$ & 31.51 & 31.17 & 33.00 & 33.48 & 0.71 & 0.7362 \\
\hline Stems (\%) & $27.64^{\mathrm{c}}$ & $32.91^{\mathrm{bc}}$ & $37.50^{\mathrm{ab}}$ & $42.77^{\mathrm{a}}$ & 1.84 & 0.0042 \\
\hline Dead Material (\%) & 43.41 & 32.98 & 34.32 & 34.56 & 2.10 & 0.0553 \\
\hline $\mathrm{CP}(\%)$ & 8.68 & 8.69 & 7.79 & 7.34 & 0.54 & 0.6448 \\
\hline NDF $(\%)$ & 68.50 & 70.85 & 70.45 & 70.57 & 0.56 & 0.4687 \\
\hline $\operatorname{ADF}(\%)$ & 39.74 & 39.50 & 39.55 & 39.32 & 0.44 & 0.9918 \\
\hline CF $(\%)$ & 30.20 & 30.60 & 31.70 & 32.05 & 0.52 & 0.4256 \\
\hline MM (\%) & 11.75 & 11.89 & 9.82 & 9.41 & 0.51 & 0.3636 \\
\hline $\mathbf{E E}(\%)$ & $2.33^{\mathrm{a}}$ & $1.47^{\mathrm{b}}$ & $0.74^{\text {bc }}$ & $0.52^{\mathrm{c}}$ & 0.21 & 0.0007 \\
\hline Lignin (\%) & 2.76 & 3.79 & 3.42 & 3.86 & 0.21 & 0.2152 \\
\hline IVDMD (\%) & 53.31 & 48.88 & 52.95 & 50.74 & 1.19 & 0.6298 \\
\hline
\end{tabular}

SEM: Standard error of mean; TADFM: Total Available of Dry Forage Mass; ACH: Average Canopy Height; DM: Dry Matter; CP: Crude Protein; NDF: Neutral Detergent Fiber; ADF: Acid Detergent Fiber; CF: Crude Fiber; MM: Mineral Matter; EE: Ether Extract; IVDMD: In Vitro Dry Matter Digestibility. (Own authorship).

\section{Production of Urochloa brizantha cv. Marandu during grazing phase}

Data with the production and canopy height of Urochloa brizantha cv. Marandu during grazing were shown in Table 3.

Significant interaction was observed between grazing and season for all variables presented in Table 3. The interactions were presented in the form of graphs, with Figure 4 representing the interaction of the total availability of dry forage mass, Figure 5 of the daily forage accumulation and Figure 6 of the average canopy height. 
Table 3. Production, daily forage accumulation and canopy height of Urochloa brizantha cv. Marandu, submitted to grazing methods.

\begin{tabular}{|c|c|c|c|c|c|c|}
\hline \multicolumn{3}{|c|}{ Fixed effects } & \multicolumn{4}{|c|}{$\begin{array}{c}\text { Variables } \\
\text { Mainly Effects }\end{array}$} \\
\hline Grazing & N_source & Season & $\begin{array}{l}\text { TADFM } \\
\left(\mathrm{kg} \mathrm{ha}^{-1}\right)\end{array}$ & $\begin{array}{c}\text { DFA } \\
\left(\mathrm{kg} \mathrm{ha}^{-1}\right)\end{array}$ & $\begin{array}{c}\text { Pre- } \\
\text { grazing } \\
\text { ACH } \\
(\mathbf{c m})\end{array}$ & $\begin{array}{c}\text { Post- } \\
\text { grazing } \\
\text { ACH } \\
\text { (cm) }\end{array}$ \\
\hline Deferred & & & 10372 & 131 & 41.52 & 28.02 \\
\hline Rotated & & & 6530 & 126 & 33.14 & 23.37 \\
\hline & Nitrate & & 8504 & 125 & 37.08 & 27.20 \\
\hline & Urea & & 8397 & 132 & 37.57 & 24.19 \\
\hline & & Winter & 8588 & 113 & 37.92 & 30.63 \\
\hline & & Spring & 8503 & 132 & 35.06 & 27.15 \\
\hline & & Summer & 8950 & 192 & 44.46 & 32.71 \\
\hline & & Autumn & 7763 & 76 & 31.87 & 15.30 \\
\hline \multicolumn{7}{|c|}{ Average Data } \\
\hline Average & & & 8258.72 & 128.38 & 36.29 & 25.70 \\
\hline SEM & & & 508.43 & 10.18 & 1.89 & 2.39 \\
\hline \multicolumn{7}{|c|}{ Statistics Probabilities } \\
\hline Grazing & & & $<.0001$ & 0.6902 & 0.0149 & 0.0570 \\
\hline N_source & & & 0.7065 & 0.5680 & 0.7797 & 0.1977 \\
\hline Season & & & 0.0242 & $<.0001$ & $<.0001$ & $<.0001$ \\
\hline Grazing *N_source & & & 0.7183 & 0.5326 & 0.7622 & 0.2820 \\
\hline Grazing*Season & & & $<.0001$ & 0.0150 & $<.0001$ & $<.0001$ \\
\hline N_source*Season & & & 0.4445 & 0.3462 & 0.7781 & 0.6358 \\
\hline Grazing *Season*N_source & & & 0.2617 & 0.3530 & 0.5145 & 0.8668 \\
\hline
\end{tabular}

SEM: Standard error of mean; TADFM: Total Available of Dry Forage Mass (average per season); DFA: Daily Forage Accumulation; ACH: Average Canopy Height. (Own authorship).

The deferred pasture had the highest production of dry forage mass in winter $\left(11368 \mathrm{~kg} \mathrm{ha}^{-1}\right)$, followed by 10245 and $10541 \mathrm{~kg} \mathrm{ha}^{-1}$ in spring and autumn, respectively, and the lowest production in summer $\left(9332 \mathrm{~kg} \mathrm{ha}^{-1}\right)$. In rotated pasture, the high production of dry forage mass was observed in summer $\left(8567.47 \mathrm{~kg} \mathrm{ha}^{-1}\right)$, followed by 5807.56 and $6761.28 \mathrm{~kg} \mathrm{ha}^{-1}$ in winter and spring, respectively, with the lowest production in autumn (4989.4 $\left.\mathrm{kg} \mathrm{ha}^{-1}\right)$. Among grazing methods, deferred was higher than rotated pasture in all seasons, except in the summer that both were similar (Figure 4).

High daily forage accumulation was reported in the summer on deferred pastures $(231.72 \mathrm{~kg}$ $\mathrm{ha}^{-1}$ ) and low in the autumn $60.06 \mathrm{~kg} \mathrm{ha}^{-1}$; during the winter and spring the accumulation was similar, being 94.65 and $137.06 \mathrm{~kg} \mathrm{ha}^{-1}$, respectively. In the rotated grazing method, the daily accumulation of forage was higher and similar in winter $\left(131.55 \mathrm{~kg} \mathrm{ha}^{-1}\right)$, spring $\left(127.09 \mathrm{~kg} \mathrm{ha}^{-1}\right)$ and summer (153.01 $\left.\mathrm{kg} \mathrm{ha}^{-1}\right)$, being lower in autumn $\left(91.91 \mathrm{~kg} \mathrm{ha}^{-1}\right)$. Comparing the two grazing methods, there is a significant difference between them in the summer, with the highest DFA in the deferred (231.72 vs. $153.01 \mathrm{~kg} \mathrm{ha}^{-1}$ ) (Figure 5). 
In pre and post-grazing the average canopy height in the deferred pasture was 50 and $40 \mathrm{~cm}$ in winter, 44 and $32 \mathrm{~cm}$ in spring, 43 and $30 \mathrm{~cm}$ in summer and $36 \mathrm{~cm}$ in autumn. In the autumn, the experimental animals from the deferred pasture went to rotated pasture, to seal the pasture for the second experimental year, this explains the fact that there is no post grazing in this season. In the rotated pasture the highest average canopy height in the pre and post-grazing was observed in the summer (43 and $30 \mathrm{~cm}$ ), the other seasons behaved statistically equal. Differences between grazing methods were observed in pre and post-grazing in winter and spring, with deferred pasture being superior in both seasons (Figure 6).

Figure 4. Graph depicting the interaction between grazing and seasons on the total available of dry forage mass.

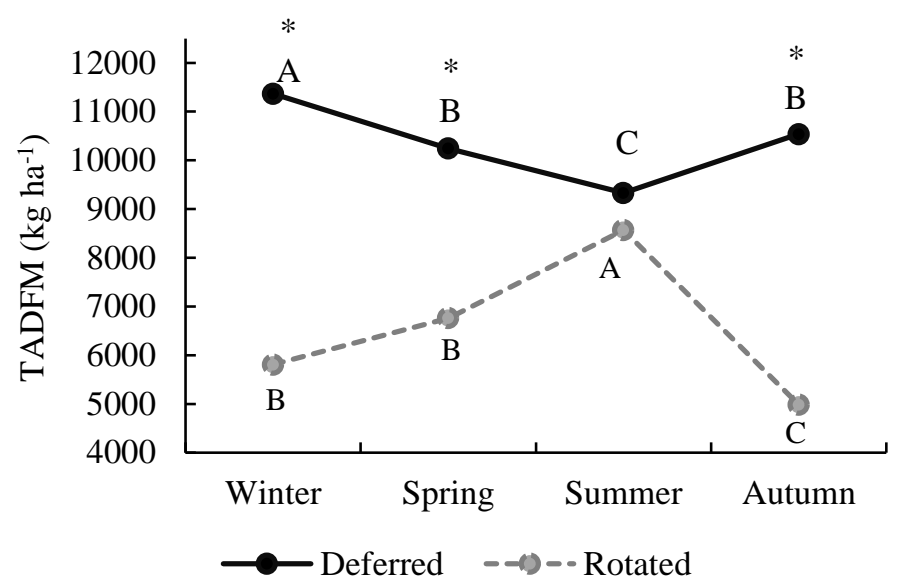

Uppercase letters: within grazing methods differs at $\mathrm{P} \leq 0.05$; asterisk $(*)$ : indicates difference within seasons at $\mathrm{P} \leq 0.05$. (Own authorship).

Figure 5. Graph depicting the interaction between grazing and seasons on the daily forage accumulation.

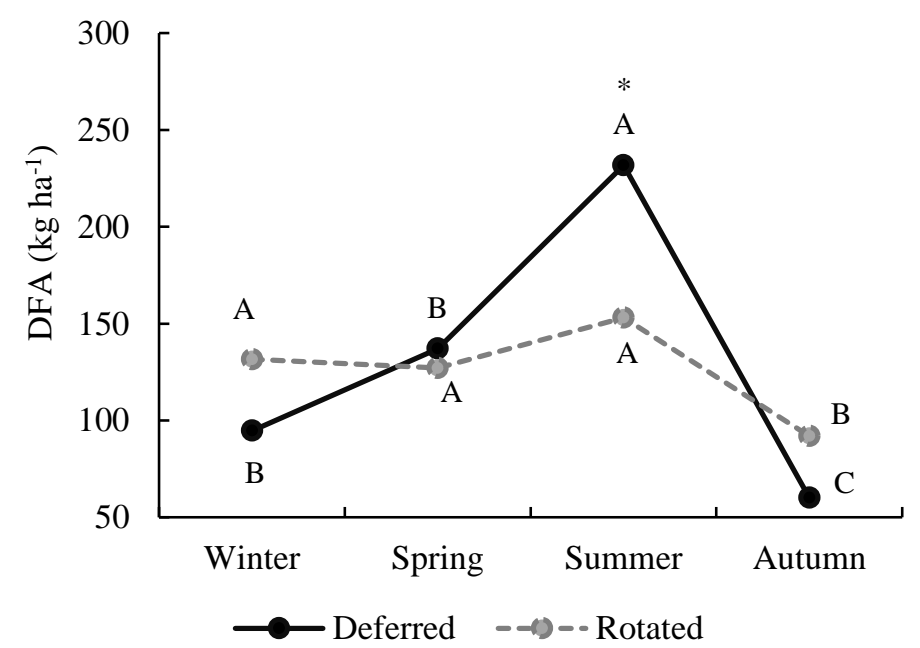

Uppercase letters: within grazing methods differs at $\mathrm{P} \leq 0.05$; asterisk $(*)$ : indicates difference within seasons at $\mathrm{P} \leq 0.05$. (Own authorship). 
Figure 6. Graph depicting the interaction between grazing and seasons on the average canopy height.

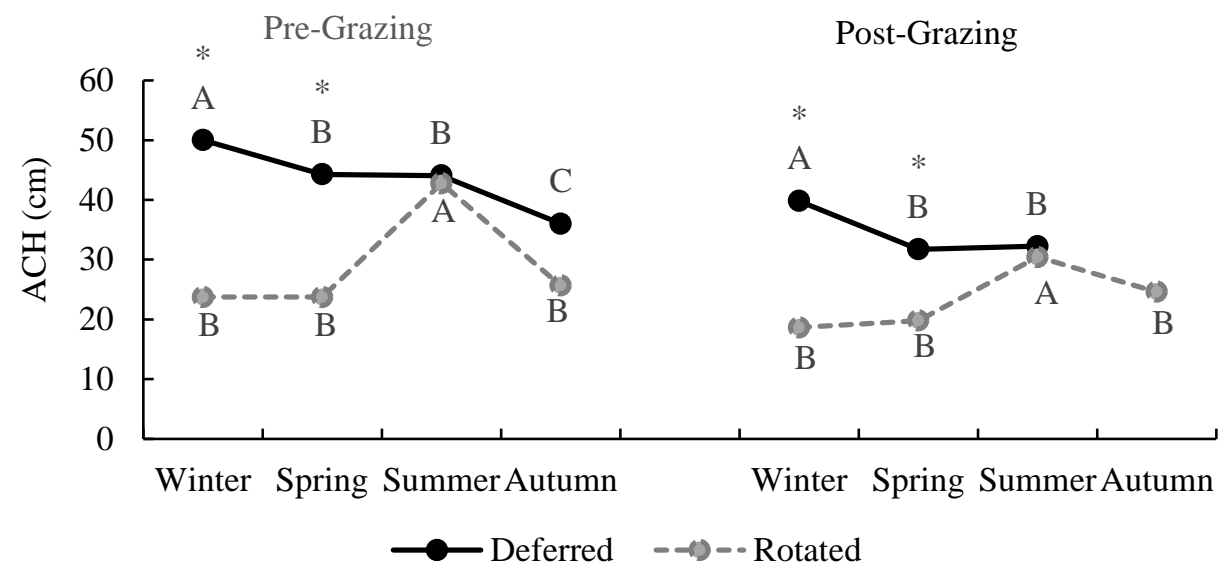

Uppercase letters: within grazing methods differs at $\mathrm{P} \leq 0.05$; asterisk $(*)$ : indicates difference within seasons at $\mathrm{P} \leq 0.05$. (Own authorship).

\section{Morphology of Urochloa brizantha cv. Marandu during grazing phase}

Significant interaction was observed between grazing and season for all variables presented in Table 4. The interactions were presented in the form of graphs (Figure 7).

Table 4. Morphological characteristics of Urochloa brizantha cv. Marandu, submitted to grazing methods.

\begin{tabular}{|c|c|c|c|c|c|c|c|c|}
\hline \multirow{3}{*}{\multicolumn{3}{|c|}{ Fixed effects }} & \multicolumn{6}{|c|}{ Variables } \\
\hline & & & \multicolumn{6}{|c|}{ Mainly Effects } \\
\hline & & & \multicolumn{3}{|c|}{$(\%)$} & \multicolumn{3}{|c|}{$\left(\mathrm{kg} \mathrm{ha}^{-1}\right)$} \\
\hline Grazing & N_source & Season & Leaf & Stems & $\begin{array}{c}\text { Dead } \\
\text { Material }\end{array}$ & Leaf & Stems & $\begin{array}{c}\text { Dead } \\
\text { Material }\end{array}$ \\
\hline Deferred & & & 30.94 & 32.14 & 36.54 & 3469.80 & 3348.57 & 3787.03 \\
\hline Rotated & & & 29.91 & 30.26 & 42.14 & 2576.23 & 2247.71 & 2395.40 \\
\hline & Nitrate & & 31.56 & 30.28 & 39.41 & 3174.68 & 2722.60 & 3144.60 \\
\hline & Urea & & 29.29 & 32.12 & 39.27 & 2871.35 & 2873.68 & 3037.83 \\
\hline & & Winter & 26.80 & 31.06 & 42.34 & 2286.34 & 2926.18 & 3334.91 \\
\hline & & Spring & 29.05 & 28.96 & 43.17 & 2204.82 & 2579.85 & 3659.34 \\
\hline & & Summer & 35.28 & 32.15 & 34.86 & 3427.12 & 2886.01 & 3088.61 \\
\hline & & Autumn & 30.58 & 32.63 & 36.99 & 4173.79 & 2800.53 & 2282.01 \\
\hline \multicolumn{9}{|c|}{ Average Data } \\
\hline Average & & & 30.43 & 30.56 & 39.79 & 3019.05 & 2650.25 & 3091.22 \\
\hline SEM & & & 1.28 & 1.01 & 1.77 & 192.17 & 222.47 & 197.41 \\
\hline \multicolumn{9}{|c|}{ Statistics Probabilities } \\
\hline Grazing & & & 0.3831 & 0.4428 & 0.1488 & 0.2856 & 0.0220 & $<.0001$ \\
\hline N_source & & & 0.0637 & 0.1905 & 0.9411 & 0.1439 & 0.4383 & 0.5595 \\
\hline Season & & & 0.0006 & 0.1521 & 0.0029 & $<.0001$ & 0.0172 & 0.0004 \\
\hline Grazing*1 & _source & & 0.0542 & 0.6534 & 0.3908 & 0.8051 & 0.5979 & 0.2038 \\
\hline Grazing* & eason & & $<.0001$ & 0.0002 & $<.0001$ & 0.0011 & $<.0001$ & 0.0002 \\
\hline N_source & Season & & 0.4741 & 0.7756 & 0.8984 & 0.8546 & 0.1345 & 0.7004 \\
\hline Grazing* & eason*N_so & rce & 0.4427 & 0.9283 & 0.9375 & 0.2002 & 0.2384 & 0.5878 \\
\hline
\end{tabular}

SEM: Standard error of mean. (Own authorship).

A high percentage of leaves was observed in summer and autumn, followed by moderate 
production in winter and low in spring in deferred pastures. In the rotated pasture, the highest percentages were noticed in the spring and summer and the lowest in the winter and autumn. Comparing the two grazing methods studied, it was observed that in the spring the rotated pasture had the highest percentage of leaves and in the autumn the highest percentage was in deferred pasture (Figure 7A).

The percentages of stems in winter and autumn were elevated, followed by lower leaf production in spring and summer in deferred pastures. In rotated pasture, the highest percentage of stems were observed in the summer. Comparing the two grazing methods studied, it was observed that in summer the rotated pasture had the highest percentage of stems and in winter and autumn the highest percentage was in deferred pasture (Figure 7A).

In winter and summer, the percentage of dead material was statistically equal, being lower than found in spring and higher than summer in deferred pastures. During the winter and autumn in the rotated pasture, high percentages of dead material were observed, 49 and 50\%, respectively, being higher than spring (36\%) and summer (34\%). In winter and autumn, rotated pasture showed the highest percentages of dead material compared to deferred pastures, while in spring the highest percentages were observed in deferred pasture (Figure 7A).

The kilograms of leaf per hectare in the deferred pastures was better in the autumn (6236), already in the summer (5354) and, in the winter (4543), decreasing in the spring $(3,370)$. In the rotated pastures, the largest amount of leaves were found in the summer (4682), already in the spring (3186) and, in the winter (2227), but was lower in the autumn (1387). Among the grazing methods it was observed differences in two seasons, in winter and autumn, in both the deferred pasture was higher compared to the rotated one in the production of leaves. (Figure 7B).

The kilograms of stems per hectare was influenced by grazing and seasons. In deferred pastures, winter and autumn were superior to spring and summer, while in rotated pastures, winter and autumn were lower than spring, which in turn was lower than summer. Significant difference between grazing methods was observed in winter and autumn. In both seasons the deferred had higher kilograms of stems per hectare (Figure 7B).

A large amount of dead material was observed in the spring, followed by moderate amounts in the winter and summer and smaller in the autumn, in deferred pastures. In rotated pastures, the amount of dead material found in all seasons does not differ statistically. Comparing grazing methods, differences were observed in winter and spring. In these seasons the largest amount of dead material 
per hectare was in deferred pastures (Figure 7B).

Figure 7. Graphs representing the interaction between grazing and seasons on the morphological characteristics of Urochloa brizantha cv. Marandu, submitted to grazing methods.
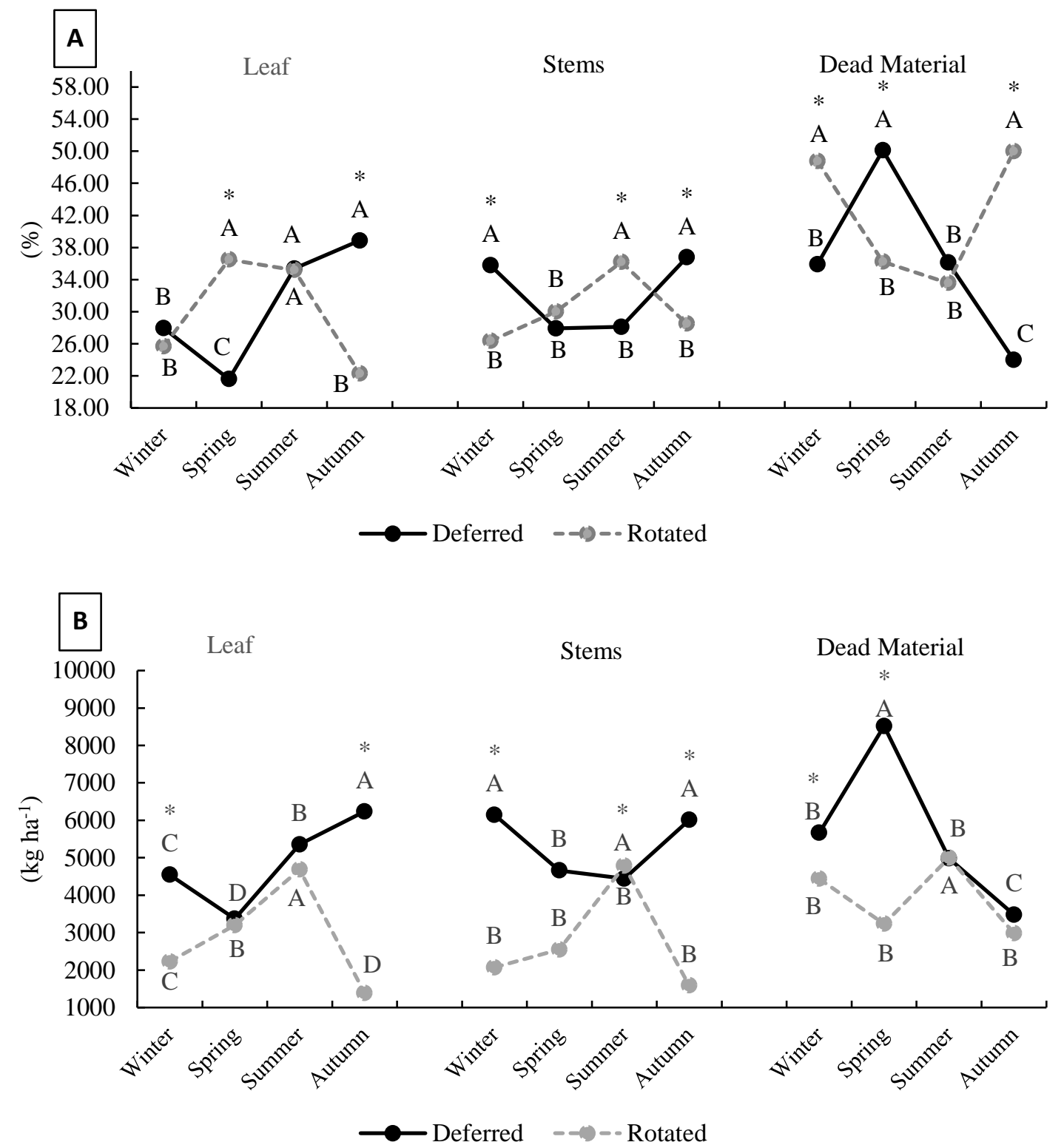

Uppercase letters: within grazing methods differs at $\mathrm{P} \leq 0.05$; asterisk $(*)$ : indicates difference within seasons at $\mathrm{P} \leq 0.05$. (Own authorship). 


\section{Nutritional Value of Urochloa brizantha cv. Marandu during grazing phase}

The seasons influenced the mineral matter of Urochloa brizantha cv. Marandu independently to grazing methods $(\mathrm{P}<0.05)$. The highest percentage of $\mathrm{MM}$ was in the summer, moderate in the spring and autumn and low in the winter (Table 5).

Significant interactions were observed between grazing and season for the variables CP, NDF, ADF, CF, LIG and IVDMD (Table 5), and these interactions were represented in graphs in Figure 8.

Table 5. Nutritional value of Urochloa brizantha cv. Marandu (whole plant), submitted to grazing methods.

\begin{tabular}{|c|c|c|c|c|c|c|c|c|c|c|}
\hline \multirow{2}{*}{\multicolumn{3}{|c|}{ Fixed effects }} & \multicolumn{8}{|c|}{ Variables } \\
\hline & & & \multicolumn{8}{|c|}{ Mainly Effects (\%) } \\
\hline Grazing & N_source & Season & $\mathbf{C P}$ & NDF & ADF & $\mathbf{C F}$ & LIG & $\mathbf{E E}$ & MM & IVDMD \\
\hline Deferred & & & 6.06 & 73.73 & 44.91 & 35.42 & 5.26 & 2.04 & 8.11 & 55.98 \\
\hline \multirow[t]{7}{*}{ Rotated } & & & 6.63 & 72.90 & 46.57 & 37.12 & 6.00 & 1.92 & 8.05 & 55.45 \\
\hline & Nitrate & & 6.59 & 72.87 & 45.78 & 36.20 & 5.59 & 1.93 & 8.39 & 56.13 \\
\hline & Urea & & 6.09 & 73.76 & 45.70 & 36.34 & 5.67 & 2.03 & 7.78 & 55.30 \\
\hline & & Winter & 4.89 & 75.83 & 48.48 & 37.75 & 6.13 & 1.86 & $7.51^{\mathrm{c}}$ & 51.63 \\
\hline & & Spring & 6.37 & 73.63 & 45.87 & 35.99 & 6.14 & 2.34 & $8.21^{\mathrm{b}}$ & 54.02 \\
\hline & & Summer & 7.29 & 71.76 & 44.76 & 36.01 & 5.10 & 1.95 & $8.73^{\mathrm{a}}$ & 61.43 \\
\hline & & Autumn & 6.83 & 72.03 & 43.86 & 35.32 & 5.14 & 1.78 & $7.88^{b}$ & 55.78 \\
\hline \multicolumn{11}{|c|}{ Average Data } \\
\hline Average & & & 6.34 & 73.31 & 45.58 & 36.12 & 5.63 & 1.98 & 8.15 & 55.71 \\
\hline SEM & & & 0.25 & 0.43 & 0.47 & 0.28 & 0.19 & 0.09 & 0.13 & 0.91 \\
\hline \multicolumn{11}{|c|}{ Statistics Probabilities } \\
\hline Grazing & & & 0.6977 & 0.5171 & 0.3041 & 0.3358 & 0.0006 & 0.5316 & 0.8941 & 0.7329 \\
\hline N_source & & & 0.7332 & 0.4879 & 0.9155 & 0.8672 & 0.3496 & 0.5792 & 0.0797 & 0.6042 \\
\hline Season & & & $<.0001$ & $<.0001$ & 0.0004 & 0.0004 & 0.0198 & 0.1912 & 0.0028 & $<.0001$ \\
\hline Grazing*N_source & & & 0.6679 & 0.5811 & 0.2133 & 0.5679 & 0.1516 & 0.8698 & 0.8217 & 0.7543 \\
\hline Grazing*Season & & & 0.0014 & 0.0253 & 0.0138 & 0.0050 & 0.0047 & 0.4213 & 0.2824 & 0.0021 \\
\hline N_source*Season & & & 0.4695 & 0.2516 & 0.9467 & 0.7980 & 0.9873 & 0.7631 & 0.7668 & 0.3774 \\
\hline Grazing*Season*N_source & & & 0.6054 & 0.4313 & 0.1785 & 0.1164 & 0.1727 & 0.9990 & 0.6952 & 0.0856 \\
\hline
\end{tabular}

SEM: Standard error of mean; CP: Crude Protein; NDF: Neutral Detergent Fiber; ADF: Acid Detergent Fiber; CF: Crude Fiber; LIG: Lignin; EE: Ether Extract; MM: Mineral Matter; IVDMD: In Vitro Dry Matter Digestibility. (Own authorship).

In deferred pastures, the highest percentage of crude protein $(\mathrm{CP})$ was in summer $(7.06 \%)$ and autumn (7.28\%), moderate in spring (5.36\%) and lowest in winter (4.53\%). In rotated pastures, the best crude protein rates were in spring $(7.37 \%)$ and summer $(7.52 \%)$, moderate in autumn $(6.37 \%)$ and lowest in winter $(5.24 \%)$. The difference between the methods was observed in the spring, where the rotated had a higher percentage of CP compared to the deferred (Figure 8A).

The neutral detergent fiber (NDF) was higher in winter (76\%) and spring (75\%), followed by lower percentages in summer $(72 \%)$ and autumn $(71 \%)$ in deferred pastures. In the rotated, the 
percentage peak of NDF was in winter $(75.7 \%)$ and lower in the other seasons. Deferred and rotated differ in the spring, with deferred being higher than rotated (Figure $8 \mathrm{~B}$ ).

In deferred pastures, higher rates of acid detergent fiber (ADF) were observed in winter (46.38\%) and spring (46.55\%), moderate in summer (44.50\%) and low in autumn $(42.21 \%)$. In the rotated, the percentage peak of ADF was in winter (50.27\%) and lower in the other seasons. Deferred and rotated differ in winter and autumn, with rotated being higher than deferred (42.21 vs. $45.51 \%$ ) (Figure 8C).

The crude fiber (CF) rate was higher in winter (36.42\%), spring (36.05\%) and summer (35.49\%), and lower in autumn (33.71\%) in deferred pastures. In the rotated, the percentage peak of CF was in winter (39.07\%) and lower in the other seasons. Deferred and rotated differ in autumn, with rotated being higher than deferred (Figure 8D).

A high percentage of lignin was reported in the spring (5.98\%), moderate in the summer $(5.32 \%)$ and autumn $(5.04 \%)$ and low in the winter $(4.71 \%)$ in the deferred pastures. In the rotated, the percentage peak of lignin was in winter $(7.56 \%)$ and lower in the other seasons. Deferred and rotated differ in winter, with rotated being higher than deferred (Figure 8E).

The percentage peak of in vitro dry matter digestibility (IVDMD) was in summer $(60.39 \%)$ and lower in the other seasons, in winter $(55.88 \%)$, in spring $(52.66 \%)$ and in autumn (55\%) in deferred pastures. In the rotated pastures, the peak of IVDMD was also in summer $(62.47 \%)$, moderate in spring (55.37\%) and autumn (56.57\%), and low in winter (47.38\%). Among grazing, there was a significant difference in winter and spring, in winter the difference was superior and in spring inferior in deferred pastures (Figure 8F).

Figure 8. Graphs representing the interaction between grazing and seasons on the qualitative components of Urochloa brizantha cv. Marandu, submitted to grazing methods.
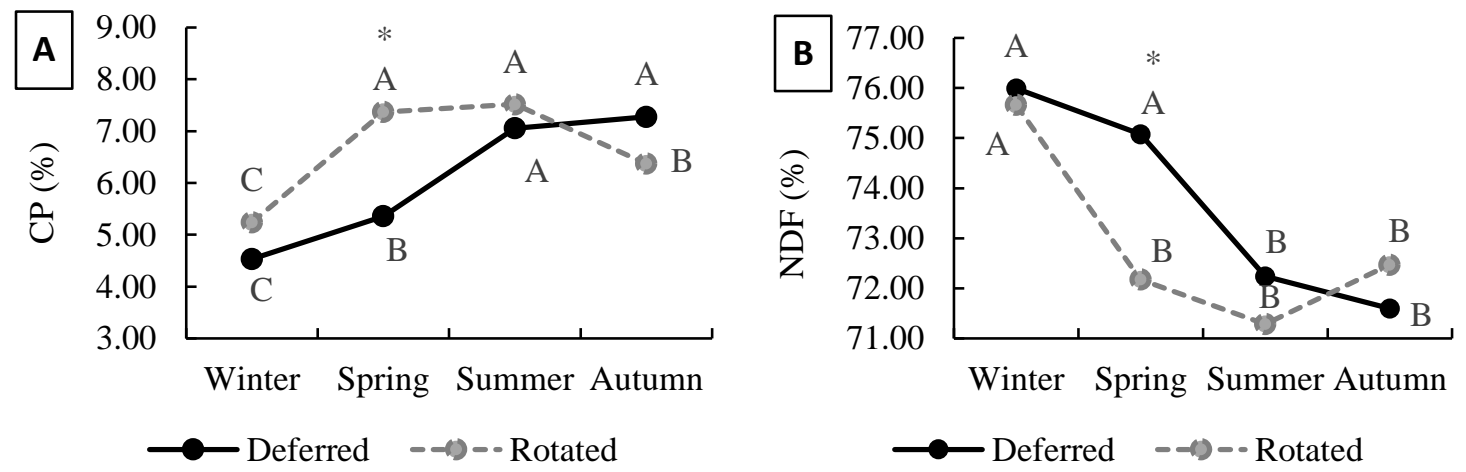

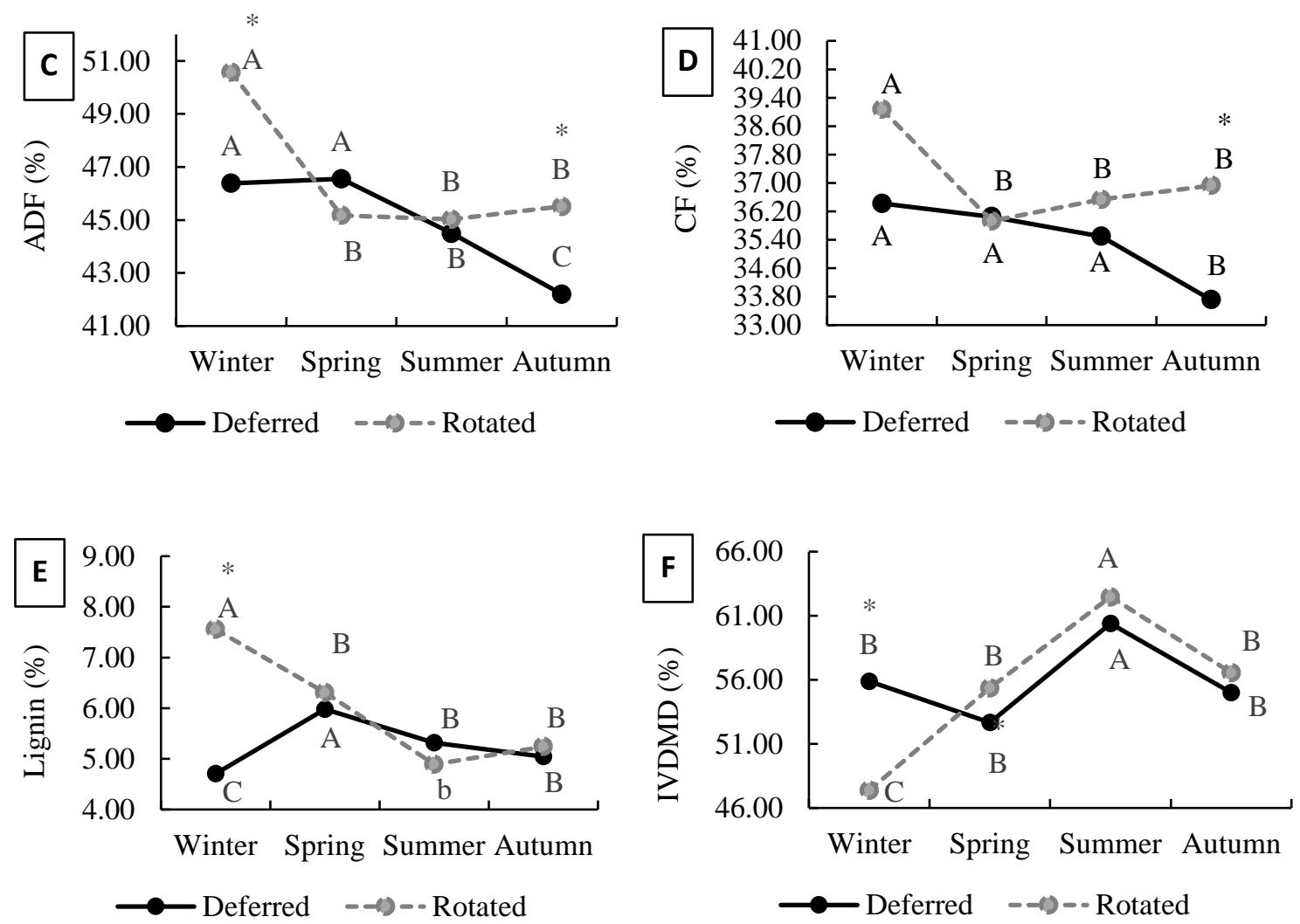

Uppercase letters: within grazing methods differs at $\mathrm{P} \leq 0.05$; asterisk $(*)$ : indicates difference within seasons at $\mathrm{P} \leq 0.05$. (Own authorship).

The seasons influenced the CP, ADF and IVDMD of Urochloa brizantha cv. Marandu harvested by animals estimated through grazing simulation $(\mathrm{P}<0.05)$. Higher $\mathrm{CP}$ was observed in the autumn, moderate in the spring and summer and lower in the winter. The ADF was influenced by the season, where the highest percentage was in the winter, moderate in the spring and low in the summer and autumn. The IVDMD was different between all seasons, as the percentages gradually increased in crescent order in the respective seasons: spring $(70.25 \%)$, winter $(75.48 \%)$, autumn $(82.17 \%)$ and summer $(85.57 \%)$ (Table 6).

Significant interaction was observed between grazing and season for the variables NDF, CF, LIG, EE and MM (Table 5), and the interactions are represented in graphs in Figure 9. 
Table 6. Nutritional value of Urochloa brizantha cv. Marandu harvested by animals estimated through grazing simulation.

\begin{tabular}{|c|c|c|c|c|c|c|c|c|c|c|}
\hline \multirow{2}{*}{\multicolumn{3}{|c|}{ Fixed effects }} & \multicolumn{8}{|c|}{ Variables } \\
\hline & & & \multicolumn{8}{|c|}{ Mainly Effects (\%) } \\
\hline Grazing & N_source & Season & $\mathbf{C P}$ & NDF & ADF & CF & LIG & $\mathbf{E E}$ & MM & IVDMD \\
\hline Deferred & & & 10.82 & 64.73 & 33.23 & 28.00 & 2.39 & 3.59 & 10.44 & 78.92 \\
\hline \multirow[t]{7}{*}{ Rotated } & & & 11.04 & 64.57 & 34.09 & 28.40 & 3.33 & 3.96 & 10.30 & 77.82 \\
\hline & Nitrate & & 11.27 & 64.12 & 33.39 & 28.04 & 2.80 & 3.79 & 10.59 & 78.84 \\
\hline & Urea & & 10.60 & 65.17 & 33.92 & 28.36 & 2.91 & 3.76 & 10.15 & 77.90 \\
\hline & & Winter & $9.74^{\mathrm{c}}$ & 64.97 & $36.97^{\mathrm{a}}$ & 30.59 & 4.59 & 4.51 & 10.19 & $75.48^{\mathrm{c}}$ \\
\hline & & Spring & $10.28^{\mathrm{b}}$ & 66.73 & $35.11^{\mathrm{b}}$ & 29.34 & 4.14 & 3.91 & 9.97 & $70.25^{\mathrm{d}}$ \\
\hline & & Summer & $10.64^{\mathrm{b}}$ & 64.66 & $31.40^{\mathrm{c}}$ & 27.46 & 0.86 & 3.12 & 10.89 & $85.57^{\mathrm{a}}$ \\
\hline & & Autumn & $13.07^{\mathrm{a}}$ & 62.23 & $31.13^{\mathrm{c}}$ & 25.42 & 1.85 & 3.55 & 10.43 & $82.17^{\mathrm{b}}$ \\
\hline \multicolumn{11}{|c|}{ Average Data } \\
\hline Average & & & 10.86 & 64.65 & 33.66 & 28.2 & 2.86 & 3.77 & 10.37 & 78.76 \\
\hline SEM & & & 0.32 & 0.39 & 0.52 & 0.41 & 0.32 & 0.13 & 0.11 & 1.13 \\
\hline \multicolumn{11}{|c|}{ Statistics Probabilities } \\
\hline Grazing & & & 0.8744 & 0.7534 & 0.0864 & 0.2744 & $<.0001$ & 0.0006 & 0.6435 & 0.2687 \\
\hline N_source & & & 0.2869 & 0.0505 & 0.2694 & 0.3716 & 0.0761 & 0.7175 & 0.1781 & 0.3380 \\
\hline Season & & & 0.0008 & 0.0001 & 0.0003 & $<.0001$ & $<.0001$ & $<.0001$ & 0.0006 & $<.0001$ \\
\hline Grazing*N_source & & & 0.9758 & 0.7274 & 0.7676 & 0.7785 & 0.2561 & 0.7388 & 0.7260 & 0.7212 \\
\hline Grazing*Season & & & 0.4544 & 0.0269 & 0.1116 & 0.0151 & $<.0001$ & $<.0001$ & 0.0041 & 0.1858 \\
\hline N_source*Season & & & 0.4373 & 0.7063 & 0.0566 & 0.0589 & 0.0922 & 0.2472 & 0.4512 & 0.1342 \\
\hline Grazing*Season*N_source & & & 0.3039 & 0.6080 & 0.3981 & 0.5780 & 0.8900 & 0.6154 & 0.2081 & 0.4641 \\
\hline
\end{tabular}

SEM: Standard error of mean; CP: Crude Protein; NDF: Neutral Detergent Fiber; ADF: Acid Detergent Fiber; CF: Crude Fiber; LIG: Lignin; EE: Ether Extract; MM: Mineral Matter; IVDMD: In Vitro Dry Matter Digestibility. (Own authorship).

In the deferred pastures, the NDF rate was elevated in the spring $(68.07 \%)$, moderate in the winter (64.84\%), lower rate in the autumn $(62.41 \%)$ and the summer (63.59\%) was statistically equal to the winter and autumn. In the rotated pastures, the percentage of NDF was lower in the autumn $(62.05 \%)$ and higher around 65\% in the other seasons. Differences between grazing methods were observed in spring and summer; therefore, the percentage of NDF in spring $(68.07 \%)$ was high in deferred pastures and in summer $(65.74 \%)$ in rotated pastures (Figure 9A).

The percentage of $\mathrm{CF}$ in deferred pastures was higher in winter (31.44\%), moderate in spring (28.61\%) and low in summer (26.68\%) and autumn (25.29\%). In rotated pastures, high rates of CF were found in winter (29.75\%), moderate in spring (30.01\%), in summer (28.24\%), and low in autumn (25.54\%). In winter and summer there was a difference in the percentage of CF between grazing methods; in winter, deferred pastures had a higher rate of CF and summer was the opposite (Figure 9B).

A high content of lignin was observed in winter (4.45\%), followed by a slightly lower content in spring $(2.54 \%)$, autumn $(1.72 \%)$ and a lower content in summer $(0.83 \%)$ in deferred pastures. In 
rotated pastures, the percentage peak of lignin was found in spring $(5.73 \%)$, decreasing in winter $(4.72 \%)$, autumn $(1.97 \%)$ and summer $(0.89 \%)$, respectively. The lignin content between grazing methods were the same in all seasons, except in spring, where the highest lignin content was observed in deferred pastures (Figure 9C).

In deferred pastures, the highest EE content was in winter $(4.50 \%)$, moderate in summer (3.40\%) and autumn (3.45\%) and lowest in spring (3.02\%). In rotated, the highest EE content was in winter (4.52\%) and spring (4.81\%), moderate in autumn (3.66\%) and low in summer (2.85\%). In spring and summer, a difference was observed between grazing methods, in spring the EE content was elevated in rotated pastures and in summer the opposite occurred (Figure 9D).

The highest content of MM was in summer (11.17\%), moderate autumn (10.39\%) and lowest in winter $(9.86 \%)$. In spring $(10.34 \%)$ was similar to winter and autumn. In rotated pastures, the highest MM content was in winter (10.52\%), summer (10.62\%), and autumn (10.48\%), but lowest in spring $(9.60 \%)$. There were no statistical differences between grazing methods in the seasons (Figure 9E).

Figure 9. Graphs representing the interaction between grazing and seasons on the nutritional value of Urochloa brizantha cv. Marandu harvested by animals estimated through grazing simulation.
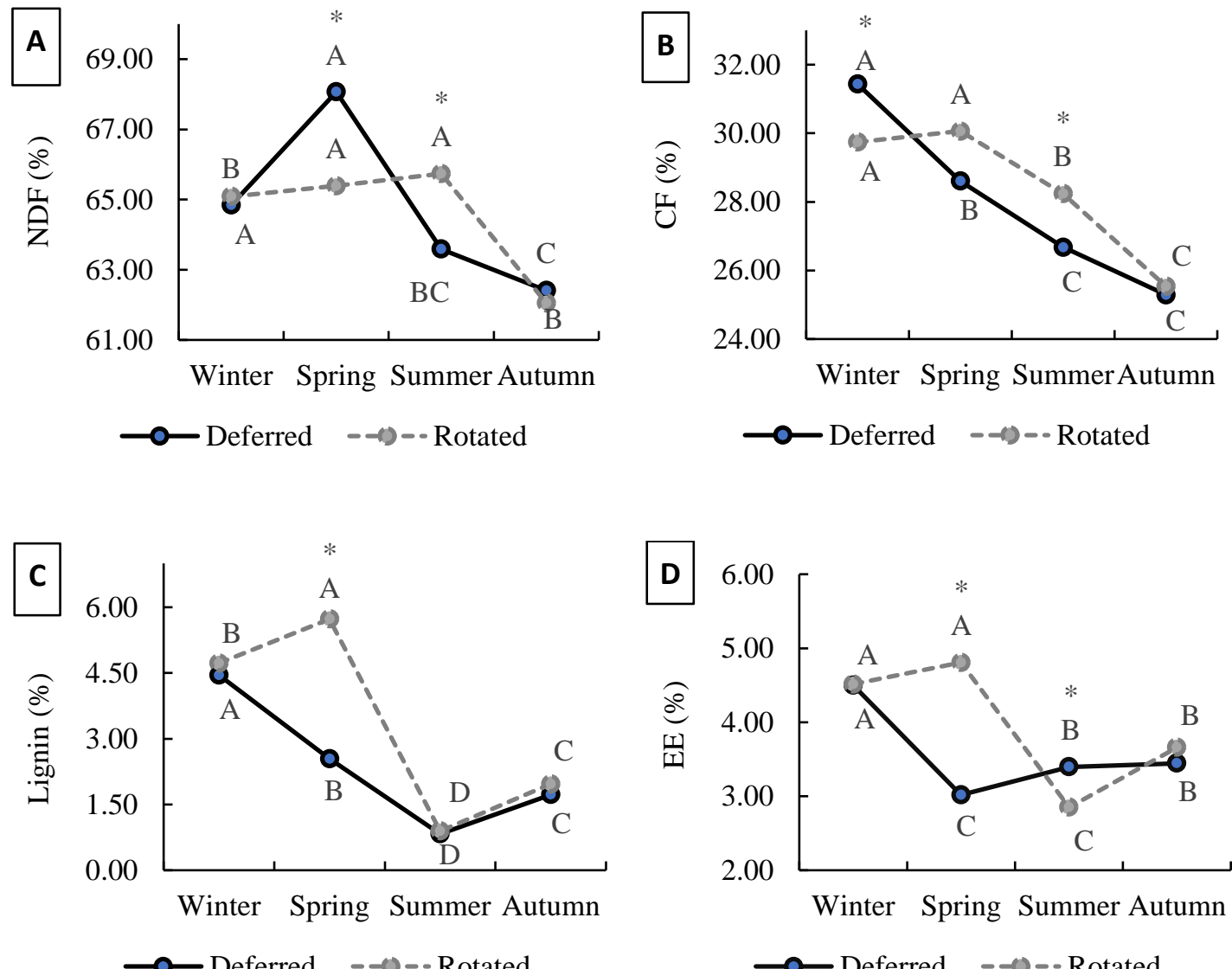


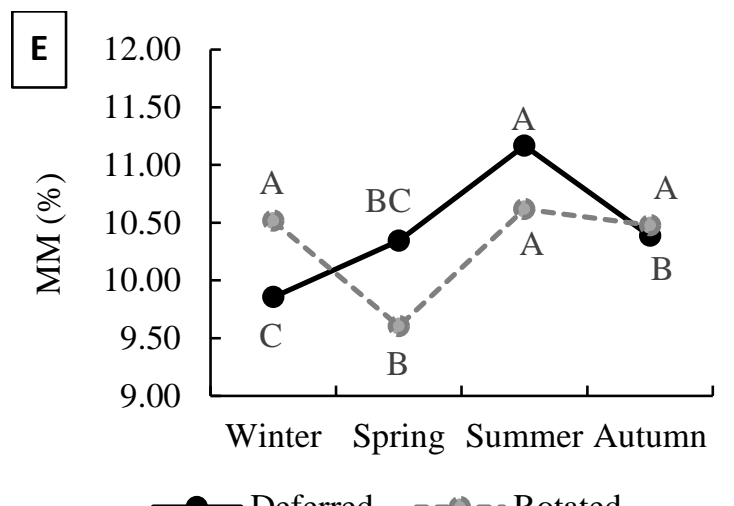

Uppercase letters: within grazing methods differs at $\mathrm{P} \leq 0.05$; asterisk $(*)$ : indicates difference within seasons at $\mathrm{P} \leq 0.05$. (Own authorship).

\section{Responses of heifers submitted to different grazing methods and nitrogen source}

The statistical differences found for the variables ALW, ADG and $\mathrm{CH}_{4}$ in the seasons were shown in Table 7. Statistical difference was observed in the ALW (average live weight) of heifers, as expected, the average live weight was increasing in the seasons, from winter to autumn. The ADG and $\mathrm{CH}_{4}$ per area was higher in the summer, moderate in the spring and low in the winter and autumn.

Heifers emitted more methane per kilogram of average daily gain in the autumn $\left(0.771 \mathrm{~kg} \mathrm{ha}^{-}\right.$ ${ }^{1}$ per day), and the other seasons were statistically the same. The daily production of enteric methane per animal unit was higher in summer (245.23 g) and autumn (253.99 g), moderate in spring (219.49 $\mathrm{g})$ and lower in winter (172.02 g).

Significant interaction was observed between grazing and season for the variables ADG (Average Daily Gain) and AU (Animal Unit) (Table 7), the interactions were represented in graphs, in Figure 10 and 11. 
Table 7. Animal performance, enteric methane production and stocking rate of Nellore heifers grazing Urochloa brizantha cv. Marandu, submitted to grazing methods and nitrogen source during the seasons.

\begin{tabular}{|c|c|c|c|c|c|c|c|c|c|}
\hline \multirow{2}{*}{\multicolumn{3}{|c|}{ Fixed effects }} & \multicolumn{7}{|c|}{ Variables } \\
\hline & & & \multicolumn{7}{|c|}{ Mainly Effects } \\
\hline \multirow{2}{*}{ Grazing } & \multirow{2}{*}{ N_source } & \multirow{2}{*}{ Season } & ADG & ALW & ADG & $\mathrm{CH}_{4}$ & $\mathrm{CH}_{4} / \mathrm{ADG}$ & $\mathrm{CH}_{4} / \mathrm{AU}$ & $\mathbf{A U}$ \\
\hline & & & (kg) & (kg) & $\left(\mathrm{kg} \mathrm{ha}^{-1}\right)$ & $\begin{array}{c}\left(\mathrm{kg} \mathrm{ha}^{-1}\right. \\
\left.\text { day }^{-1}\right)\end{array}$ & $\begin{array}{c}\left(\mathrm{kg} \mathrm{ha}^{-1}\right. \\
\left.\text { day }^{-1}\right)\end{array}$ & $\left(\right.$ g day $\left.^{-1}\right)$ & $\left(\mathbf{h a} \mathbf{a}^{-1}\right)$ \\
\hline \multirow{8}{*}{$\begin{array}{c}\text { Deferred } \\
\text { Rotated }\end{array}$} & \multirow{8}{*}{$\begin{array}{c}\text { Nitrate } \\
\text { Urea }\end{array}$} & & 0.433 & 475.11 & 1.79 & 0.84 & 0.511 & 231.09 & 3.42 \\
\hline & & & 0.434 & 453.77 & 1.51 & 0.74 & 0.556 & 214.27 & 3.38 \\
\hline & & & 0.421 & 461.83 & 1.64 & 0.85 & 0.591 & 225.89 & 3.68 \\
\hline & & & 0.446 & 467.06 & 1.66 & 0.73 & 0.476 & 219.47 & 3.12 \\
\hline & & Winter & 0.402 & $397.32^{d}$ & $0.89^{\mathrm{c}}$ & $0.38^{\mathrm{c}}$ & $0.486^{\mathrm{b}}$ & $172.02^{\mathrm{c}}$ & 2.15 \\
\hline & & Spring & 0.549 & $438.25^{c}$ & $1.87^{\mathrm{b}}$ & $0.74^{\mathrm{b}}$ & $0.388^{b}$ & $219.49^{b}$ & 3.28 \\
\hline & & Summer & 0.535 & $493.78^{b}$ & $3.14^{\mathrm{a}}$ & $1.53^{\mathrm{a}}$ & $0.490^{\mathrm{b}}$ & $245.23^{\mathrm{a}}$ & 6.12 \\
\hline & & Autumn & 0.248 & $528.42^{\mathrm{a}}$ & $0.70^{\mathrm{c}}$ & $0.50^{\mathrm{d}}$ & $0.771^{\mathrm{a}}$ & $253.99^{\mathrm{a}}$ & 2.04 \\
\hline \multicolumn{10}{|c|}{ Average Data } \\
\hline \multirow{2}{*}{\multicolumn{3}{|c|}{$\begin{array}{l}\text { Average } \\
\text { SEM }\end{array}$}} & 0.44 & 464.44 & 1.65 & 0.78 & 0.54 & 222.68 & 3.43 \\
\hline & & & 0.02 & 9.57 & 0.19 & 0.09 & 0.04 & 5.24 & 0.39 \\
\hline \multicolumn{10}{|c|}{ Statistics Probabilities } \\
\hline \multicolumn{3}{|l|}{ Grazing } & 0.9738 & 0.0878 & 0.2517 & 0.3885 & 0.4978 & 0.1689 & 0.9453 \\
\hline \multicolumn{3}{|l|}{ N_source } & 0.4386 & 0.6126 & 0.9316 & 0.2641 & 0.0991 & 0.3567 & 0.2463 \\
\hline \multicolumn{3}{|c|}{ Season } & $<.0001$ & $<.0001$ & $<.0001$ & 0.0024 & 0.0051 & 0.0004 & 0.0028 \\
\hline \multicolumn{3}{|c|}{ Grazing*N_source } & 0.4034 & 0.5631 & 0.4366 & 0.9236 & 0.4635 & 0.7156 & 0.2720 \\
\hline \multicolumn{3}{|c|}{ Grazing*Season } & $<.0001$ & 0.0651 & 0.3514 & 0.6009 & 0.8114 & 0.2006 & $<.0001$ \\
\hline \multicolumn{3}{|c|}{ N_source*Season } & 0.2394 & 0.5507 & 0.7781 & 0.7385 & 0.6399 & 0.0603 & 0.3651 \\
\hline \multicolumn{3}{|c|}{ Grazing*Season*N_source } & 0.6371 & 0.9247 & 0.9605 & 0.9963 & 0.9828 & 0.3880 & 0.1222 \\
\hline
\end{tabular}

SEM: Standard error of mean; ADG: Average Daily Gain; ALW: Average Live Weight; AU: Animal Unit. (Own authorship).

Significant interaction between grazing and season was observed on the average daily gain (Figure 10). In deferred pastures, ADG was constant in all seasons, ranged from 0.560 to $0.547 \mathrm{~kg}$. In rotated pastures the worst ADG was in winter $(0.252 \mathrm{~kg})$, moderate in autumn $(0.451 \mathrm{~kg})$ and high in spring $(0.566 \mathrm{~kg})$ and summer $(0.531 \mathrm{~kg})$. In the winter, the average daily gain of heifers kept in the deferred pastures was higher $(0.560 \mathrm{~kg})$ compared to the rotated pastures $(0.252 \mathrm{~kg})$ (Figure 10). However, in the autumn due the forage stockpiling phase of the second year of experiment, the animals that were in the deferred pastures were transferred to the rotated pastures with the same nitrogen source, for this reason, there is no data on animal performance and stocking rate in autumn on deferred pastures. 
Figure 10. Graph representing the interaction between grazing and seasons on the average daily gain of Nellore heifers grazing Urochloa brizantha cv. Marandu, submitted to grazing methods and nitrogen source during the seasons.

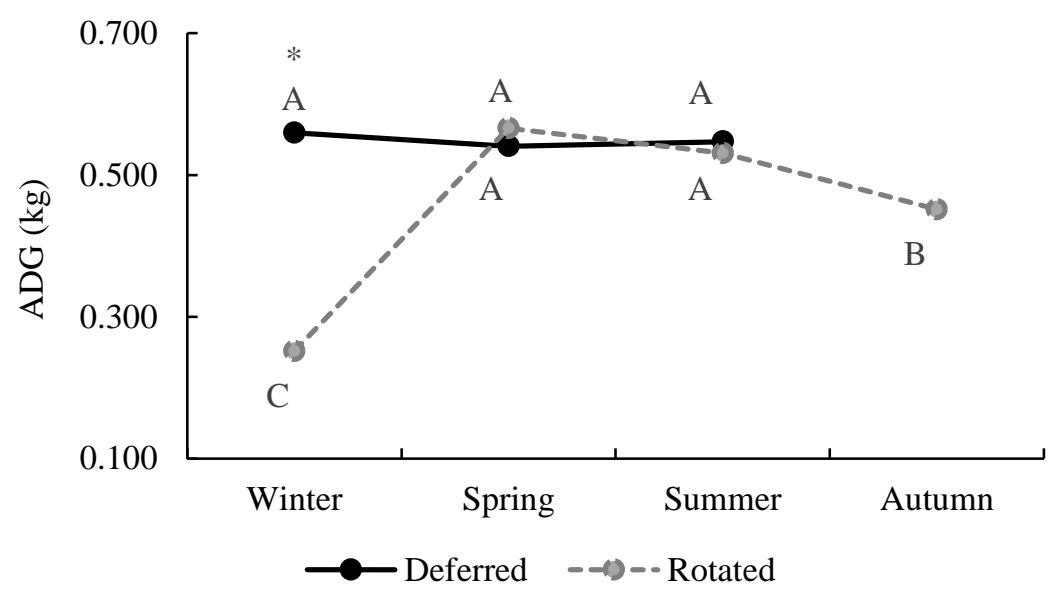

Uppercase letters: within grazing methods differs at $\mathrm{P} \leq 0.05$; asterisk $(*)$ : indicates difference within seasons at $\mathrm{P} \leq 0.05$. (Own authorship).

The stocking rate expressed in Animal Unit (AU) was 2.37 animals per hectare in winter, 4.31 in spring and 7.08 in summer in deferred pastures. In the rotated, the highest stocking rate was in summer (5.36), moderate in autumn (4.14) and low in winter (2.13) and spring (2.45). Differences between grazing methods were observed in the spring, where deferred pastures have higher AU per hectare compared to rotated pastures (4.30 vs. 2.45) (Figure 11).

Figure 11. Graph representing the interaction between grazing and seasons on the stocking rate of Nellore heifers grazing Urochloa brizantha cv. Marandu, submitted to grazing methods and nitrogen source during the seasons.

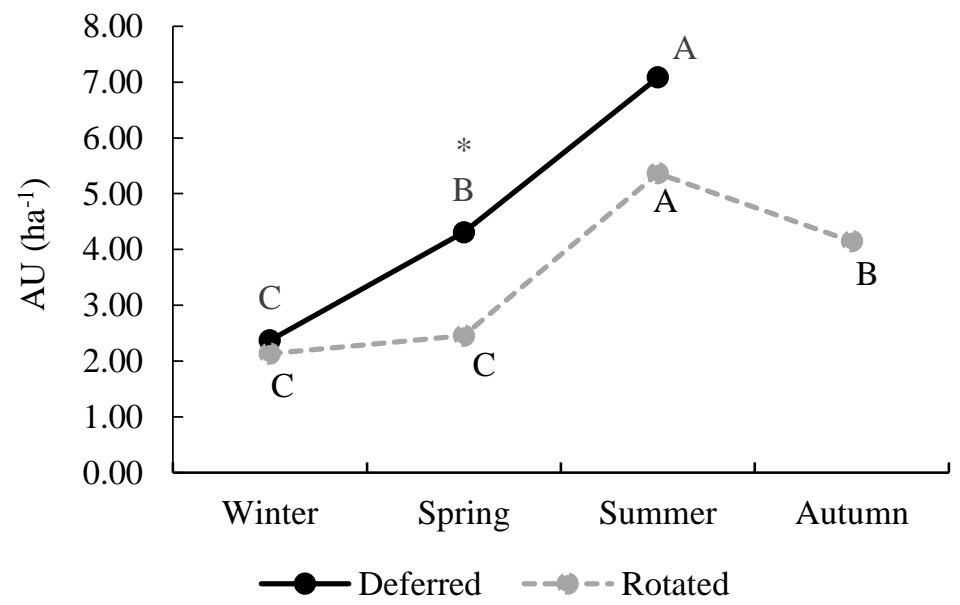

Uppercase letters: within grazing methods differs at $\mathrm{P} \leq 0.05$; asterisk $(*)$ : indicates difference within seasons at $\mathrm{P} \leq 0.05$. (Own authorship). 
There was a significant difference $(\mathrm{P}<0.05)$ between the seasons for the Forage Intake $(\mathrm{FI})$, Dry Matter Intake Total (DMIt), Forage Intake in relation to Live Weight (FILW) and Dry Matter Intake Total in relation to Live Weight variables (DMItlw) (Table 8).

The heifers FI and DMIt was elevated in summer and autumn, while in winter and spring it was low. FILW and DMItlw were higher in autumn and lower in spring, while winter was similar to summer and spring, and summer similar to autumn and winter (Table 8).

Significant interaction between grazing and nitrogen source was observed on the supplement intake (Figure 12).

Table 8. Dry matter intake of Nellore heifers grazing Urochloa brizantha cv. Marandu, submitted to grazing methods and nitrogen source during the seasons.

\begin{tabular}{|c|c|c|c|c|c|c|c|c|}
\hline \multirow{3}{*}{\multicolumn{3}{|c|}{ Fixed effects }} & \multicolumn{6}{|c|}{ Variables } \\
\hline & & & \multicolumn{6}{|c|}{ Mainly Effects } \\
\hline & & & \multicolumn{3}{|c|}{$\left(\mathrm{kg}\right.$ animal dia $\left.{ }^{-1}\right)$} & \multicolumn{3}{|c|}{$(\%)$} \\
\hline Grazing & N_source & Season & FI & SI & DMIt & FILW & SILW & DMItlw \\
\hline Deferred & & & 5.76 & 0.52 & 6.26 & 1.25 & 0.11 & 1.36 \\
\hline \multirow[t]{7}{*}{ Rotated } & & & 5.18 & 0.24 & 5.44 & 1.20 & 0.06 & 1.26 \\
\hline & Nitrate & & 5.38 & 0.31 & 5.69 & 1.21 & 0.07 & 1.28 \\
\hline & Urea & & 5.55 & 0.45 & 6.02 & 1.23 & 0.10 & 1.34 \\
\hline & & Winter & $4.05^{\mathrm{b}}$ & 0.16 & $4.22^{\mathrm{b}}$ & $1.09^{\mathrm{bc}}$ & 0.05 & $1.14^{\mathrm{bc}}$ \\
\hline & & Spring & $3.72^{\mathrm{b}}$ & 0.31 & $4.04^{\mathrm{b}}$ & $0.91^{\mathrm{c}}$ & 0.08 & $0.98^{\mathrm{c}}$ \\
\hline & & Summer & $6.51^{\mathrm{a}}$ & 0.50 & $7.01^{\mathrm{a}}$ & $1.39^{\mathrm{ab}}$ & 0.11 & $1.49^{\mathrm{ab}}$ \\
\hline & & Autumn & $7.60^{\mathrm{a}}$ & 0.54 & $8.14^{\mathrm{a}}$ & $1.52^{\mathrm{a}}$ & 0.11 & $1.62^{\mathrm{a}}$ \\
\hline \multicolumn{9}{|c|}{ Average Data } \\
\hline Average & & & 5.47 & 0.39 & 5.85 & 1.22 & 0.08 & 1.30 \\
\hline SEM & & & 0.43 & 0.06 & 0.45 & 0.08 & 0.01 & 0.08 \\
\hline \multicolumn{9}{|l|}{ Statistics Probabilities } \\
\hline Grazing & & & 0.5488 & 0.0357 & 0.4292 & 0.8253 & 0.0809 & 0.6650 \\
\hline N_source & & & 0.8545 & 0.1876 & 0.7396 & 0.9144 & 0.1425 & 0.8105 \\
\hline Season & & & 0.0001 & 0.0057 & 0.0008 & 0.0005 & 0.0799 & 0.0007 \\
\hline Grazing*N_source & & & 0.7012 & 0.3998 & 0.7931 & 0.8498 & 0.3106 & 0.9234 \\
\hline Grazing*Season & & & 0.1757 & 0.1025 & 0.1906 & 0.4905 & 0.3258 & 0.4258 \\
\hline N_source*Season & & & 0.6846 & 0.0306 & 0.8105 & 0.4879 & 0.0577 & 0.7569 \\
\hline Grazing*Season*N_source & & & 0.3284 & 0.2129 & 0.4822 & 0.4570 & 0.1430 & 0.3935 \\
\hline
\end{tabular}

SEM: Standard error of mean; FI: Forage Intake; SI: Supplement Intake, DMIt: Dry Matter Intake Total; FILW: Forage Intake in relation to Live Weight; SILW: Supplement Intake in relation to Live Weight; DMItlw: Dry Matter Intake Total in relation to Live Weight. (Own authorship).

In the autumn heifers had a better consumption of urea $\left(0.661 \mathrm{~kg} \mathrm{dia}^{-1}\right)$, lower in winter $(0.203$ $\left.\mathrm{kg} \mathrm{dia}^{-1}\right)$ and moderate in spring $\left(0.471 \mathrm{~kg} \mathrm{dia}^{-1}\right)$ and summer $\left(0.476 \mathrm{~kg} \mathrm{dia}^{-1}\right)$. Ammonium nitrate intake was better in summer $\left(0.521 \mathrm{~kg} \mathrm{dia}^{-1}\right)$, moderate in autumn $\left(0.420 \mathrm{~kg} \mathrm{dia}^{-1}\right)$ and low in winter $\left(0.125 \mathrm{~kg} \mathrm{dia}^{-1}\right)$ and spring $\left(0.155 \mathrm{~kg} \mathrm{dia}^{-1}\right)$. Differences in supplement consumption were found 
between nitrogen sources in spring and autumn, where urea consumption was superior to ammonium nitrate in both seasons (Figure 12).

Figure 12. Supplement intake of Nellore heifers receiving two sources of nitrogen.

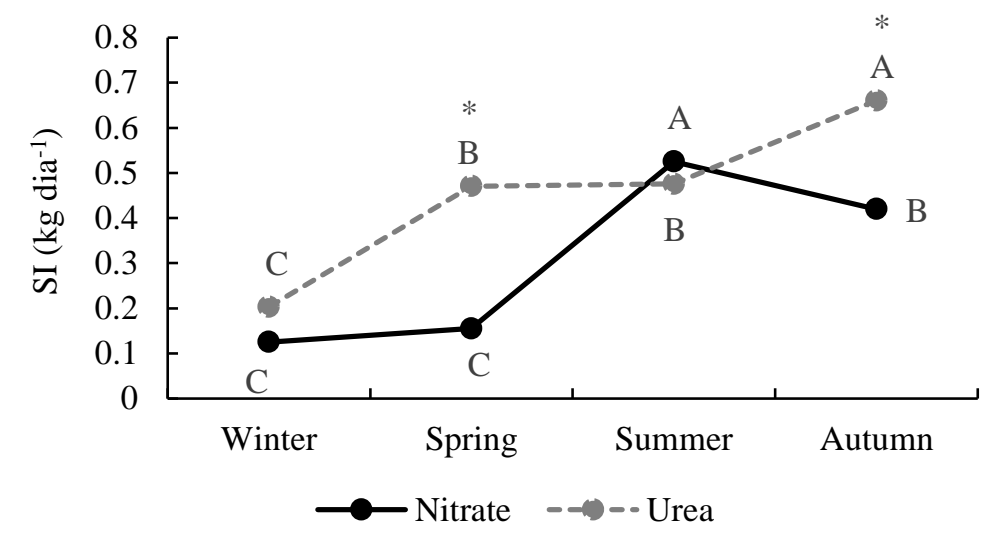

Uppercase letters: within grazing methods differs at $\mathrm{P} \leq 0.05$; asterisk $(*)$ : indicates difference within seasons at $\mathrm{P} \leq 0.05$. (Own authorship).

\section{DISCUSSION}

Productive, morphological, and chemical components of Urochloa brizantha cv. Marandu during the forage stockpiling

The forage mass had an intense growth between 21 and 42 days of forage stockpiling of the order of $50.1 \%\left(2630.5 \mathrm{~kg} \mathrm{ha}^{-1}\right)$, followed by $16.9 \%\left(889.25 \mathrm{~kg} \mathrm{ha}^{-1}\right)$ between 42 and 63 days and $33 \%$ between 63 and 84 days (1725.5 $\mathrm{kg} \mathrm{ha}^{-1}$ ) (Table 2).

Since the forage production is dependent on temperature and radiation and is limited by the availability of nutrients and water, the increased production of forage recorded between 21 and 42 days of forage stockpiling can be explained by the better water balance, temperature (Figure 2) and response to nitrogen fertilization carried out in March 2019. Tropical grasses have an optimal temperature range between 25 and $35^{\circ} \mathrm{C}$ (SANTOS et al., 2008), the critical minimum temperature being $15^{\circ} \mathrm{C}$ (ROLIM, 1980). The recommended rainfall for Marandu grass is around 1,000 and 2,500 $\mathrm{mm}$ per year, although it produces in places with rainfall close to $700 \mathrm{~mm}$ per year (COSTA, 2001; OLIVEIRA et al., 2006).

Brougham (1957) described three phases in the sigmoid curve of forage accumulation, lasting around 4-5 weeks each phase. In phase 1, called logarithmic, the accumulation is limited by the low leaf area and low light capture; however it is accelerated with time. In phase 2, called linear, the 
accumulation is high and more or less constant, which reflects the potential of the grass in the environment. In the third phase, called the asymptotic phase, the senescence process increases. Eventually, the senescence rate equals the leaf production rate, at which point the forage accumulation decreases to zero. In some conditions, the senescence of leaves can exceed the production of leaves. In this case, the forage mass may decrease over time.

During the forage stockpiling, it was no possible to verify the slow initial phase (logarithmic) of the sigmoid curve elucidated by Brougham (1957), possibly because the cutting heights were not drastic enough, as the pastures were sealed with an average canopy height of $30 \mathrm{~cm}$. Thus, it is more understandable that these pastures have already started to grow in the linear phase of the curve (phase $2)$.

Santos et al. (2018), when evaluating the Marandu grass deferred for 80 days at canopy heights of 15 and $30 \mathrm{~cm}$, found the most productive pasture was the sealed at $30 \mathrm{~cm}$ (7400 vs. $\left.5600 \mathrm{~kg} \mathrm{ha}^{-1}\right)$. Despite the similarity in the initial canopy height and forage stockpiling period, in the present study, the forage mass produced was slightly higher $\left(8890 \mathrm{~kg} \mathrm{ha}^{-1}\right)$.

During the forage stockpiling period, the canopy height increased linearly. This was expected because the forage was constantly growing and free of defoliation by grazing, possibly there was competition by the light between the tillers and, in response, there was stems lengthening to expose the leaves on a higher plane in the canopy (CARNEVALLI et al., 2006). Santos et al. (2009a) also observed an increase in the length of stems of Urochloa decumbens cv. Basilisk during the pasture forage stockpiling period.

Deferred pastures showed high rates of growth; however, the expressive stems elongation modify the structures and cause the lodging of the grass, mainly in the Urochloa genus, resulting in a higher proportion of structures unsuitable for cattle consumption (SANTOS et al., 2009).

The levels of ether extract did not exceed the limit 6\% EE in which values above this limit could limit the consumption of dry matter by ruminants (SOUZA et al., 2009). In forage plants, the levels of ether extract in the dry matter can vary up to $4 \%$ (CARDOSO et al., 2006).

Decreases in EE can be noted during the forage stockpiling period. In mature plants there is a translocation of the ether extract to the grains, reducing the EE content in the leaves and stems (RODRIGUES JÚNIOR et al., 2015). 
In both grazing methods, the total available of dry forage mass was over the entire grazing phase above $2000 \mathrm{~kg} \mathrm{ha}^{-1}$ recommended by Minson (1990) and NRC (1996) and considered in several publications as being a critical mass, below which consumption and selectivity would be impaired. The observed values were still above $4600 \mathrm{~kg} \mathrm{ha}^{-1}$ suggested by Euclides et al. (1992), which would be the most appropriate critical mass for tropical species. Therefore, probably the forage mass, during grazing, was above the minimum to guarantee the selectivity and avoid a decrease in forage consumption.

Gerdes et al. (2000), evaluating marandu grass with 35 days of rest, found 3,760 kg ha-1 in spring, 2,030 kg ha ${ }^{-1}$ in summer, 1,190 kg ha-1 in autumn and $950 \mathrm{~kg} \mathrm{ha}^{-1}$ of forage mass in winter, the forage dry mass found in this study was higher than these values in the two grazing methods studied in all seasons (Figure 4).

Botrel et al. (1999) reported that Marandu grass produced 16.27 tonnes of dry forage mass per hectare annually, 13.09 tonnes during the rainy season, and 3.28 tonnes in the dry period, which corresponded to $20 \%$ of the total production.

In this experiment, approximately $70.45 \%$ of the annual forage accumulation in deferred pastures occurred in spring and summer, while about $29.55 \%$ occurred in autumn and winter. In rotated pastures $81.74 \%$ ocurred in winter, spring and summer, and $18.26 \%$ in autumn. These results demonstrate the typical seasonality of tropical forage production in the Southeast and Midwest regions of Brazil. In that context, Gimenes et al. (2011) also verified that, on average, $81 \%$ of the annual forage accumulation occurred in the spring and summer seasons, while that only $19 \%$ of the annual forage accumulation was recorded in the autumn and winter seasons.

\section{Morphology of Urochloa brizantha cv. Marandu during grazing phase}

The structure of the canopy is extremely important, as it determines the accessibility and the ease of harvesting the components, normally selected by grazing animals, affecting the amount of nutrients ingested (STOBBS, 1973). According to Hodgson (1990), the grazing animal's diet generally contains a high proportion of leaf blades and a low proportion of stems and dead material.

In terms of percentage of leaves, it was observed that in the rotated pastures the highest percentage was in the spring and summer. In terms of quantity per area this was verified in the summer. In the deferred pastures the high percentage of leaves was in the summer and in the autumn, but in quantity per area it was high in the autumn (Figure 7). 
In the rotated pastures, the herbage allowance was $10.08 \%$, with a stocking rate of 2.45 animals per hectare in the spring. In this season, precipitation and temperature were not limiting (Figure2). It can be concluded that there was high leaf production and low grazing pressure in this period. In the autumn the percentage of leaves decreased in rotated pastures, and this can be explained by the fact that the stocking rate (Figure 11) increased in this season, since the leaf is the preferred morphological component for grazing animals (HODGSON, 1990), decreasing the rate of appearance of new tissues associated with high senescence rates. This may have contributed to the low percentage of leaf blades and an increase in the percentage of dead material. Another fact that may explain the low production of leaves is that autumn is the beginning of the dry period, known as the season of water restrictions and unfavorable temperatures for the growth of forage. These factors certainly caused restriction on the growth of the leaves, since the growth plant, although genetically determined, is quite influenced by environment variables, as temperature (MARTUSCELLO et al., 2005), water availability and nutrients (SILVA et al., 2009).

The nitrogen fertilization started in November/2019 and ended in March/2019. Possibly a greater supply of nitrogen to the plants in the summer allowed pastures to be able to produce a higher quantity of leaves.

The percentage of leaves in winter was the same for the two grazing methods (Figure 7A), however, also in winter, a larger weight of leaves per hectare was observed in the deferred pastures (Figure 7B). This is due to the fact that the deferred pastures showed a total available of dry forage mass in relation to the rotated pastures (Figure 4).

The deferred pastures remained without grazing in autumn. So, the percentage of leaves was expected to increase; however, the rotated pastures remained under grazing, decreasing the rate of appearance of new tissues associated with high senescence rates, which may have contributed to the low amount of leaf blades and an increase in dead material.

In the summer, rotated pastures had $9.57 \%$ herbage allowance, while deferred pastures had $4.42 \%$. The stocking rate was based on the herbage allowance, therefore, a higher stocking rate was observed in deferred pastures in relation to rotated pastures (Figure 11). There may have been a greater grazing pressure in the deferred pastures, causing the animals to eat more stems. More intense and frequent grazing is usually associated with greater renewal in the tiller population (UEBELE, 2002; SBRISSIA, 2004) promoting a more effective control of stems development (ZEFERINO, 2006). In rotated pastures, the animals may have had greater forage selection power, leaving the stems, changing the structure of the pasture. 
The deferred pastures were opened for grazing in the winter, therefore, during the forage stockpiling period (84 days), the canopy height increased linearly (Table 2). Possibly there was competition by the light between the tillers and, in response, there was stems lengthening, to expose the leaves on a higher plane in the canopy (CARNEVALLI et al., 2006). As in this season the herbage allowance was $11.85 \%$ the animals managed to select more leaves leaving the stems that was accumulated in the forage stockpiling.

In the autumn, the deferred pastures had an average of $36 \mathrm{~cm}$ of canopy height (Figure 6) and there were no animals grazing (forage stockpiling period of the second experimental year). The average height of the canopy without grazing may have caused tiller shading and, consequently, elongation of the stems, to expose the leaves in a higher plane of the canopy. Zeferino (2006), in a study with rotated pastures of marandu grass, observed that, when the average height of the canopy of the pre-grazing was $35 \mathrm{~cm}$, the elongation of stems was greater than in the pastures where the average height of the canopy was $25 \mathrm{~cm}$.

In winter and autumn the dry forage mass available in rotated pastures was mostly dead material, while in deferred pastures this happened in the spring (Figure 7B). The amount per hectare is dependent on the total amount of dry forage available.

\section{Nutritional value of Urochloa brizantha cv. Marandu during grazing phase}

The nutritional value refers to the forage chemical composition and digestibility (VAN SOEST, 1994). The low nutritional value of tropical forages is often cited in the literature, as the nutritional value is associated with the reduced content of crude protein and minerals, high content of fibers and the low digestibility of dry matter (EUCLIDES, 1995). Other factors, as the forage species, the cultivar, the climate, the soil and the stage of development of the plant can influence the nutritional value (VAN SOEST, 1994).

Many studies show that grazing cattle select diets resulting in chemical compositions and botanicals different from those found in forage available. They consume leaves, in preference to stems, and green forage in preference to dead material. Consequently, when compared to forage available, the diet selected by the animals presents greater nutritional value.

The highest concentration of protein occurs in the leaves, being of high biological value, and

of high quality amino acid. In pastures deferred in summer and autumn, the available dry forage mass was mainly composed of leaves (35.36 and $38.86 \%$ ), respectively. In the rotated pastures, the largest proportion of leaves was in the spring and summer. There was a positive correlation between leaves 
and protein, when an increase in leaves was observed, an increase in the $\mathrm{CP}$ content was also observed.

In deferred pastures, the $\mathrm{CP}$ of whole plant was below the critical limit in winter $(4.53 \%)$ and spring (5.36\%), while in rotated pastures was in winter (5.24) and in autumn (6.37). In these same periods, a low percentage of leaves was observed in the pastures. In the seasons with a low CP content, a high NDF content was observed. The percentage of NDF is inversely correlated to the CP content (VITOR et al., 2009).

The deferred pastures were sealed for 84 days and opened for grazing in the winter. In that season the dry forage mass was mostly composed of stems (35.76\%) and dead material (35.90\%) and also due to the thickening of the plant cell wall with advancing age, there is an increase in fibrous constituents and a reduction in $\mathrm{CP}$ levels. In the spring it was observed that most of the dry forage mass was composed of dead material (50.11\%). Possibly the low stocking rate in the anterior season (2.37 AU) caused forage leftovers and consequently a high senescence rate.

Crude protein from grazing simulation remained above 7\% in all seasons. According to Van Soest (1994), with the CP content of forages below 7\%, there is a reduction in the degradation of forage in rumen, due to inadequate levels of nitrogen for the rumen microorganisms, decreasing their population and, consequently, reducing digestibility and dry matter intake. Therefore, a higher CP content is necessary to meet the protein requirements of the animal organism.

The average percentage of NDF found in the present study for whole plant was $73.73 \%$ in deferred pastures and $72.90 \%$ in rotated pastures, slightly above that mentioned by Euclides et al. (2009) for the average of three cultivars of Urochloa brizantha in a three-year study. Santos et al. (2013) when evaluating Marandu grass (whole plant) at 35 days obtained an average higher value for NDF of $74.80 \%$.

The average percentage of NDF found in the grazing simulation was $64.73 \%$ for deferred pastures and $64.57 \%$ for rotated pastures. Comparing the whole plant and the grazing simulation of the deferred pastures, it is verified that there is a difference of $9 \%$ of NDF, while in the rotated pastures this difference was of $8.33 \%$.

According to Van Soest (1994) contents of NDF above 55-60\% in dry matter are negatively correlated with the consumption of forage. The NDF is the component of the forage more consistently associated with dry matter intake (BENETT et al., 2008), lower levels of NDF allow a greater forage 
intake by the animal. The percentage of crude protein is negatively associated with NDF and ADF, while these two are related to each other (ARAUJO et al., 2002).

The levels of ADF are related to the levels of lignin, which determine the digestibility of forage. So, decreases in ADF and lignin content results in better digestibility of forage (RODRIGUES JÚNIOR et al., 2015). The ADF of the whole plant varied from 46.38 to $42.21 \%$ in deferred pastures, in rotated pastures the variation was from 50.27 to $45.02 \%$. In the grazing simulation ADF ranged from 36.97 to $31.13 \%$ in the seasons. In the present study, it is observed that the ADF is related to structural constituents of CF and lignin, as one increases, the other increases too.

Forages with values around $30 \%$ of ADF (ideal level for good animal consumption), or less, will be consumed at high levels, while those with levels above $40 \%$ will be consumed at low levels (NUSSIO et al., 1998).

The whole plant had a high ADF content in rotated pastures in winter and autumn, while in the other seasons both grazing methods were the same. The forage harvested by the animals differed in the seasons, with a higher ADF content in the winter.

In the seasons with the highest $\mathrm{CF}$ rate, it was observed that the largest proportion of the collected forage was stems and dead material. The rate of (CF) of the whole plant ranged from 36.42 to $33.71 \%$ in deferred pastures. In rotated, the variation was 39.07 to $35.93 \%$. The percentage of CF in deferred pastures ranged from 31.44 to $25.29 \%$; in rotated pastures, the variation was from 29.75 to $25.54 \%$ in the forage harvested by the animals.

The proportion of compound lignin increases with the advance of the physiological maturity of the plants, therefore it is necessary that the forage be consumed when the lignin content is low, in relatively young plants (BARBERO et al., 2009).

The whole plant had a high percentage of lignin reported in spring (5.98\%), moderate in summer $(5.32 \%)$ and autumn $(5.04 \%)$ and low in winter $(4.71 \%)$ in deferred pastures. In rotated pastures, the percentage peak of lignin was in winter (7.56\%) and lower in other seasons. Deferred and rotated differ in winter, with rotated being higher than deferred.

Compared to the whole plant, the forage harvested by the animals had less lignin. A high content of lignin was observed in winter $(4.45 \%)$, followed by a slightly lower content in spring $(2.54 \%)$, autumn $(1.72 \%)$ and a lower content in summer $(0.83 \%)$ in deferred pastures. In rotated pastures, the percentage peak of lignin was found in spring $(5.73 \%)$, decreasing in winter $(4.72 \%)$, 
autumn (1.97\%) and summer (0.89\%), respectively. The lignin content between grazing methods were the same in all seasons, except in spring, where the highest lignin content was observed in deferred pastures.

In deferred pastures, the EE content of the forage from grazing simulation varied from 4.50 to $3.02 \%$. In rotated pasture, it varied from 4.81 to $2.85 \%$. In the spring and summer, a difference was observed between the grazing methods, in the spring the EE content was high in the rotated pastures and in the summer the opposite occurred.

The determination of mineral matter provides an indication of the concentration of mineral nutrients in the grass. The MM of the whole plant was different during the seasons, varying from 7.51 to $8.73 \%$. In the deferred pastures, the MM content of the forage harvested by the animals varied from 9.86 to $11.17 \%$, while in the rotated pastures the variation was from 9.60 to $10.62 \%$.

The reduction in rainfall reflects negatively on soil moisture, decreasing the loading of nutrients into the plant. However, according to the considerations of Castro et al. (1999), it is noteworthy that, with the maturity of the plants, a drop in mineral contents is commonly observed, due to the effect of its dilution in the dry matter produced.

The IVDMD correlates with the maturity of the plant. As the plant matures, the concentration of potentially digestible components, including carbohydrates soluble substances, protein, minerals and other cell contents, tends to decrease. At the same time, the proportions of lignin, cellulose and hemicellulose, and other indigestible fractions, such as cuticle and silica, increase. Therefore, the decrease in digestibility is expected (EUCLIDES, 2000).

The IVDMD of tropical forages is between 55 and $60 \%$. A decrease of the concentration of crude protein in the forage may be in the order of 4 to $6 \%$ (MOORE; MOTT, 1973).

\section{Responses of heifers submitted to different grazing methods and nitrogen source}

As expected, the average live weight of heifers gradually increased in the seasons throughout the experimental period. The greater average daily weight gain per area at the stations was directly related to the stocking rate, the higher the stocking, the greater the ADG per hectare.

The ADG and $\mathrm{CH}_{4}$ per area was higher in the summer, moderate in the spring and low in the winter and autumn. Heifers emitted more methane per kilogram of average daily gain in the autumn

$\left(0.771 \mathrm{~kg} \mathrm{ha}^{-1}\right)$, while in the other seasons were statistically the same. The production of enteric 
methane per animal unit was higher in summer (245.23 g) and autumn (253.99 g), moderate in spring $(219.49 \mathrm{~g})$ and lower in winter (172.02 g).

In deferred pastures, ADG was constant in all seasons, ranged from 0.560 to $0.547 \mathrm{~kg}$. The weight gain of animals kept on deferred pastures with supplementation varies from 0.490 to $0.725 \mathrm{~kg}$ per day (SILVA et al., 2016).

In rotated pastures the worst ADG was in winter $(0.252 \mathrm{~kg})$, moderate in autumn $(0.451 \mathrm{~kg})$ and high in spring $(0.566 \mathrm{~kg})$ and summer $(0.531 \mathrm{~kg})$. In the winter, the average daily gain of heifers kept in the deferred pastures was higher $(0.560 \mathrm{~kg})$ compared to the rotated pastures $(0.252 \mathrm{~kg})$ (Figure 10). However, in the autumn due the forage stockpiling phase of the second year of experiment, the animals that were in the deferred pastures were transferred to the rotated pastures with the same nitrogen source. For this reason, there is no data on animal performance and stocking rate in autumn on deferred pastures.

The nutritive value of the forage harvested by the animals was similar between the grazing methods in the winter; however, the ADG of the heifers in the rotated pastures was very low $(0.252$ $\mathrm{kg}$ ). The ADG may have been affected by the difference in available forage mass and morphological components in winter between grazing methods. In rotated pastures the available forage mass was $5807.56 \mathrm{~kg} \mathrm{ha}^{-1}$, of which $48.77 \%$ were dead material.

In rotated pastures, what may have contributed to the lower values of ADG in the autumn, was that the animals were heavier and with a different pattern of tissue deposition (muscle vs. fat) and feed conversion efficiency compared to spring and summer (VAN SOEST, 1994).

Furthermore, the inclusion of nitrate in the diet as an alternative source of non-protein nitrogen to urea have been addressed in terms of their capabilities to enhance the productive performance of ruminants (LEE; BEAUCHEMIN, 2014; HEGARTY et al., 2016). However, in the current study neither the nitrate supplementation nor the urea presented an improve on average daily gain.

The stocking was based on the herbage allowance. When there was a high availability of dry forage mass, the stocking was increased. The stocking rate expressed in Animal Unit (AU) was 2.37 animals per hectare in winter, 4.31 in spring and 7.08 in summer in deferred pastures. In the rotated, the highest stocking rate was in summer (5.36), moderate in autumn (4.14) and low in winter (2.13) and spring (2.45). Differences between grazing methods were observed in the spring, where deferred pastures have higher AU per hectare compared to rotated pastures (4.30 vs. 2.45). 
For Aguiar et al. (2005), in the rotated grazing method, with fertilization planning, soil correction and grazing management according to the season and cultivated forage. Following these criteria, it is possible to obtain a stocking rate of $6.4 \mathrm{AU} \mathrm{ha}^{-1}$ in spring, $8.3 \mathrm{AU} \mathrm{ha}^{-1}$ in summer, 4.5 $\mathrm{AU} \mathrm{ha}{ }^{-1}$ in autumn and 2.0 $\mathrm{AU} \mathrm{ha}^{-1}$ in winter. In the present study, the stocking rate was below that reported by Aguiar et al. (2005), and this should be mainly due to the herbage allowance adopted.

According to Fonseca et al. (2013), deferred pastures are characterized by stocking rates rarely exceeding 1.5 to $2.0 \mathrm{AU} \mathrm{ha}^{-1}$ per year. Considering an average stocking rate in Brazil of 0.6 $\mathrm{AU} \mathrm{ha}^{-1}$ and according to the last Agricultural Census, carried out in 2017, the average Brazilian stocking rate has been increasing with each survey, currently being $1.15 \mathrm{AU} \mathrm{ha}^{-1}$ (IBGE, 2017). The deferred pasture is a promising technology to increase the carrying capacity of pastures, in this current study, the average annual stocking rate was 4.59 $\mathrm{AU} \mathrm{ha}^{-1}$ in deferred pastures.

The production of $\mathrm{CH}_{4}$ by area differed in the seasons. It was also directly related to the stocking rate, increased animal by area, an increase in the production of $\mathrm{CH}_{4}$ by area was observed. The higher the ADG per area, the lower the emission of methane per hectare. Heifers emitted more methane per kilogram of average daily gain in the autumn $\left(0.771 \mathrm{~kg} \mathrm{ha}^{-1}\right)$, while in the other seasons were statistically the same.

Nitrogen sources did not influence $\mathrm{CH}_{4} / \mathrm{ADG}$ emissions, Duthie et al., (2018) testing the inclusion of nitrate and / or maize distilleries dark grains also found no differences in $\mathrm{CH}_{4} / \mathrm{ADG}$ emissions from steers for any nutritional treatment.

The production of enteric methane per animal unit was higher in summer (245.23 g) and autumn (253.99 g), moderate in spring (219.49 g) and lower in winter (172.02 g). Methane production by ruminants is positively correlated with DMI (BLAXTER; CLAPPERTON, 1965; JOHNSON; JOHNSON, 1995).

The composition of the ingested forage interferes with the $\mathrm{CH}_{4}$ emission by the animals. Tropical grasses have more fiber than temperate grasses, favoring acetic fermentation and thus, greater production of $\mathrm{CH}_{4}$ by the rumen (BERCHIELLI, 2012). The emission value of enteric $\mathrm{CH}_{4}$ in $\mathrm{g} \mathrm{day}^{-1}$ for kg year ${ }^{-1}$, for the two grazing methods, was $80.16 \mathrm{~kg} \mathrm{year}^{-1}$, higher than those portrayed by Berdnt (2010), in which he estimates that Brazilian emission values are $56 \mathrm{~kg} / \mathrm{year}$.

Previous studies have shown consistent reduction in methane production from cattle receiving a nitrate supplementation compared with no nitrate or urea (LIN et al., 2011; ZHOU et al., 2012). However, in the present study, the nitrogen source did not impact on $\mathrm{CH}_{4}$ production. But that was 
affected by the seasons, wherein the $\mathrm{CH}_{4}$ production per area was increased during the summer and decreased in the autumn.

The forage intake varied from 3.72 to $7.60 \mathrm{~kg} \mathrm{day}^{-1}$ in the seasons, with the highest FI observed in summer and autumn, and lowest in winter and spring. The dry matter intake total varied from 4.04 to $8.14 \mathrm{~kg} \mathrm{day}^{-1}$ and was influenced by forage intake.

FILW and DMItlw were higher in autumn and lower in spring, while winter was similar to summer and spring, and summer similar to autumn and winter. The FILW ranged from 0.91 to $1.52 \%$ and from DMItlw from 0.98 to $1.62 \%$.

In the current study, no differences were found in forage intake when the heifers were fed with nitrate or urea. This result agrees with Lee et al. (2015a, 2015b, 2015c), Guyader et al. (2015) and Olijhoek et al. (2016) where in those autors did not found differences in DMI between animals fed nitrate or urea supplemented diets.

The minimum daily forage intake is estimated at around $2 \%$ of the live weight due to the selection, however, it can be further reduced if there is physical restriction and / or the nutritional value of the forage is low (NUSSIO et al., 1998). In the seasons with low FILW and DMItlw, a high content of NDF, ADF, CF, lignin, and low IVDMD were found in the chemical composition of the forage harvested by the animals.

NDF levels above 55\% (PAULINO et al., 2001a) and ADF levels above 40\% (REIS; DA SILVA, 2011) also compromise DMI. In this work, the NDF and ADF values of the forage harvested by the animals remained very close to or above those recommended by the authors cited.

The NDF can be used to characterize the expression of two of the mechanisms that control consumption, which are the physical (physical satiety) and physiological (chemical satiety) factors, as it is directly related to the effect of rumen filling and inversely to the energy concentration of the diet (REIS; DA SILVA, 2011). The consumption of NDF above $1.2 \%$ of the animal's BW (MERTENS, 1994) would be one of the main physical mechanisms regulating the consumption of DM.

The consumption of the supplement containing urea ranged from 0.203 to $0.661 \mathrm{~kg} \mathrm{dia}^{-1}$. It was noted that the consumption had a positive relationship with the live weight of the heifers. The 
consumption of the supplement containing ammonium nitrate varied from 0.125 to $0.521 \mathrm{~kg} \mathrm{day}^{-1}$, it was noted that the consumption was lower when the inclusion of nitrate was 30\% in DM.

The effectiveness of mitigating methane emissions is reduced with the increase of nitrate levels in the feeding of ruminants, as described in a review by Leng (2014) and Van Zijderveld (2011). The inclusion of 30\% ammonium nitrate in the dry season and \% in the rainy season in the animals' supplement, may have caused a reduction in the consumption of the ammonium nitrate supplement. Nitrate tastes bitter, which lowers palatability of nitrate-based diets causing lower feed intake (LEE et al. 2014).

\section{CONCLUSION}

In the present study, there were differences in forage production, morphological components and nutritional value between grazing methods in the seasons. However, these differences did not influence the final response of the heifers' performance, being similar between grazing methods. The nitrogen source did not impact on $\mathrm{CH}_{4}$ production. Thus, based on the data presented, the deferred pasture was more attractive, as it has a lower cost of implantation and maintenance, with performance and productivity similar to rotating stocking method.

\section{REFERENCES}

ABIEC. Associação Brasileira das Indústrias Exportadoras de Carne. Beef Report Perfil da Pecuária no Brasil - Relatório Anual 2020. Disponível em: http://www.abiec.com.br/Sumario2020.aspx.

ALMEIDA, E., GOMIDE, C. A., SENICATO, L. A., \& NASCIMENTO FILHO, V. F. Cr and Yb markers determination in animal feces by energy dispersive X-ray fluorescence. International Nuclear Atlantic Conference - INAC, 8., 2007, Santos, SP, Anais, Santos, SP. Associação Brasileira de Energia Nuclear - ABEN, 2007.

ARAUJO, M. R. A.; COULMAN, B. E.; RAKOW, G. Genetic variation, heritability and progeny testing in meadow bromegrass. Plant Breeding, v. 121, n. 2, p. 417-424, 2002.

ARCHIMEDE, H.; EUGÈNE, M.; MAGDELEINE, C.M.; BOVAL, M.; MARTIN, C.; MORGAVI, D.P.; DOREAU, M. Comparison of methane production between $\mathrm{C} 3$ and $\mathrm{C} 4$ grasses and legumes. Animal Feed Science and Technology, v.166-167, p.59-64, 2011.

BACH, A.; CALSAMIGLIA, S.; STERN, M.D. Nitrogen metabolism in the rumen. Journal of dairy science, v. 88, p. E9-E21, 2005.

BARBERO, L.M.; CECATO, U.; LUGÃO, S.M.B.; GOMES, J.A.N.; LIMÃO, V.A.; BASSO, K.C. Produção de forragem e componentes morfológicos em pastagem de coastcross consorciada com amendoim forrageiro. Revista Brasileira de Zootecnia , v.38, p.788-795, 2009. 
BENETT, C. G. S.; BUZETTI, S.; SILVA, K. S.; BERGAMASCHINE, A. F.; FABRICIO, J. A. Produtividade e composição bromatológica do capim Marandu a fontes e doses de nitrogênio. Ciência e Agrotecnologia, Lavras, v. 32, n. 5, p. 1629-1636, 2008.

BERCHIELLI, T.T.; MESSANA, J.D.; CANESIN, R.C. Produção de metano entérico em pastagens tropicais. Revista Brasileira de Saúde e Produção Animal, v. 13, n. 4, 2012.

BERNDT A. Impacto da pecuária de corte brasileira sobre os gases do efeito estufa. In: $7^{\mathbf{0}}$ Simpósio de Produção de Gado de Corte. Viçosa: Universidade Federal de Viçosa, 2010.

BLAXTER, K. L., AND J. L. CLAPPERTON. 1965. Prediction of the amount of methane produced by ruminants. Br. J. Nutr. 19:511-522.

BRASIL. Instituto de Geografia e Estatística. Censo Agropecuário Brasileiro, 2017. Acesso em 22 de Maio de 2021. Disponível em: https://censos.ibge.gov.br/agro/2017/templates/censo_agro/resultadosagro/pecuaria.html.

BRASIL. Ministério da Ciência e Tecnologia. Inventário brasileiro das emissões e remoções antrópicas de gases de efeito estufa: informações gerais e valores preliminares, 2009.

BROUGHAM, R.W. 1957. Pasture growth rate studies in relation to grazing management. New Zealand Society of Animal Production, 17: 46-55.

BUSTAMANTE, M.M.C.; NOBRE, C.A.; SMERALDI, R.; AGUIAR, A.P.D.; BARIONI, L.G.; FERREIRA, L.G.; LONGO, K.; MAY, P.; PINTO, A.S.; OMETTO, J.P.H.B. Estimating greenhouse gas emissions from cattle raising in Brazil. Climatic change, v. 115, n. 3-4, p. 559-577, 2012.

CABRAL, C.H.; PAULINO, M.F.; DETMANN, E.; FILHO, S.C.V.; BARROS, L.V.; VALENTE, E.E. L.; BAUER, M.O.; CABRAL, C.E.A. Levels of supplementation for grazing beef heifers. Asian-Australasian journal of animal sciences; v. 27; n. 6; p. 806; 2014.

CARDOSO, E. da C.; BRAGA, E.; CAMARÃO, A. P.; MORENO, W. C.; SOUZA, S. S.; MOUTINHO, J. Teores de proteína bruta, extrato etéreo e minerais de gramíneas nativas Paspalum repens e Paspalum fasciculatum de ecossistemas de várzea do Baixo Amazonas, Pará, Brasil. Pasturas Tropicales, Cali, v. 28, n. 1, p. 67-71, 2006.

CARLOTO, M.N.; EUCLIDES, V.P.B.; MONTAGNER, D.B.; LEMPP, B.; DIFANTE, G.D.S.; PAULA, C. D. (2011). Desempenho animal e características de pasto de capim-xaraés sob diferentes intensidades de pastejo, durante o período das águas. Pesquisa Agropecuária Brasileira, 46, 97104.

CARNEVAlli, R. A.; DA SILVA, S. C.; BUENO, A. A. O.; UEBELE, M. C.; BUENO, F. O.; SILVA, G. N.; MORAES, J. P. Herbage production and grazing losses in Panicum maximum cv. Mombaça under four grazing managements. Tropical Grasslands, v. 40, n. 3, p. 165-176, 2006.

CASAGRANDE, D.R.; RUGGIERI, A.C.; JANUSCKIEWICZ, E.R.; GOMIDE, J.A.; REIS, R.A.; VALENTE, A.L. da S. Características morfogênicas e estruturais do capim-marandu manejado sob pastejo intermitente com diferentes ofertas de forragem. Revista Brasileira de Zootecnia, v.39, p.2108-2115, 2010.

CASSIANO, E.C.O. Nitrato de cálcio como mitigador da emissão de metano em bovinos. 2017. Tese (Doutorado em Nutrição e Produção Animal) - Faculdade de Medicina Veterinária e Zootecnia, Universidade de São Paulo, Pirassununga, 2017. 
CASTRO, F. G. F.; HADDAD, C. M.; VIEIRA, A. C.; VENDRAMINI, J. M. B.; HEISECKE, O. R. P. Época de corte, produção, composição químico-bromatológica e digestibilidade da matéria seca da grama estrela Florico. Scientia Agricola, Piracicaba, v. 56, n. 1, p. 225-233, 1999.

COSTA, N. de L. Manejo de pastagens de Brachiaria brizantha cv. Marandu em Rondônia. Porto Velho: Embrapa Rondônia, 2001. 3 p. (Recomendações técnicas, 33).

DA SILVA, S.C. Manejo do pastejo para obtenção de forragem de qualidade. In. Pires, A.V. Bovinocultura de corte. Piracicaba: Fealq, 2010 v.l, p.433-447.

DEMARCHI, J.J.A.A.; MANELLA, M.Q.; PRIMAVESI, O.; FRIGHETTO, R.T.S.; ROMERO, L.A.; BERNDT, A.; LIMA, M.A. Effect of seasons on enteric methane emissions from cattle grazing Urochloa brizantha. Journal of Agricultural Science, v.8, p.106-115, 2016.

DUTHIE, C.-A. et al. The effect of dietary addition of nitrate or increase in lipid concentrations, alone or in combination, on performance and methane emissions of beef cattle. animal, v. 12, n. 2, p. 280$287,2018$.

EMPRESA BRASILEIRA DE PESQUISA AGROPECUÁRIA - EMBRAPA. Centro Nacional de Pesquisa de Solos (Rio de Janeiro, RJ). Sistema Brasileiro de Classificação de Solos. Brasília, Embrapa Produção de Informação; Rio de Janeiro, Embrapa-SPI/Embrapa-CNPS, 1999. 412p.

EUCLIDES FILHO, K., FIGUEIREDO, G.R., EUCLIDES, V.P.B. 1995. Eficiência de produção de vacas de corte com diferentes potenciais para produção de leite. Pesq. Agropec. Bras., 30(7):10031007.

EUCLIDES, V. P. B. et al. Avaliação de diferentes métodos para estimar o valor nutritivo de forragens sob pastejo. Revista Brasileira de Zootecnia, v.21, n.4, p. 691- 702, 1992.

EUCLIDES, V.P.B.; CARDOSO, E.G.; MACEDO, M.C.M.; OLIVEIRA, M.P. Consumo voluntário de Brachiaria decumbens cv. Basilisk e Brachiaria brizantha cv. Marandu sob pastejo. Revista da Sociedade Brasileira de Zootecnia, v.29, p.2200-2208, 2000.

EUCLIDES, V.P.B.; FLORES, R.; MEDEIROS, R.N.; OLIVEIRA, M.P. Diferimento de pastos de braquiária cultivares Basilisk e Marandu, na região do Cerrado. Pesquisa Agropecuária Brasileira, v.42, n.2, p.273-280, 2007.

EUCLIDES, V.P.B.; MACEDO, M.C.M.; VALLE, C.B. do; DIFANTE, G.S.; BARBOSA, R.A.; CACERE, E.R. Valor nutritivo da forragem e produção animal em pastagens de Brachiaria brizantha. Pesquisa Agropecuária Brasileira, v.44, p.98-106, 2009.

EUCLIDES, V.P.B.; MEDEIROS, S.R. de. Suplementação alimentar de bovinos em pastagens. In: CARVALHO, L. de A.; ZOCCAL, R.; MARTINS, P. do C.; ARCURI, P.B.; MOREIRA, M.S. de P. (Ed.). Tecnologia e gestão na atividade leiteira. Juiz de Fora: Embrapa Gado de Leite, 2005. p.203240.

EUCLIDES, V.P.B.; VALLE, C.B. do; SILVA, J.M. da; VIEIRA, A. Avaliação de forrageiras tropicais manejadas para a produção de feno-em-pé. Pesquisa Agropecuária Brasileira, v.25, p.393407, 1990.

FAO. FOOD AND AGRICULTURE ORGANIZATION. Mitigation of greenhouse gas emissions in livestock production. Animal Production and Health. Rome, 2013. 
FONSECA, D.M.; SANTOS, M.E. R.; GOMES, V.M. Pastejo diferido. In: REIS, R. A.; BERNARDES, T. F.; SIQUEIRA, G. R. (Ed.). Forragicultura: ciência, tecnologia e gestão dos recursos forrageiros. Jaboticabal: Maria de Lourdes Brandel-ME, 2013. 714p.

FRANCO, G.L.; AGUIAR JÚNIOR, C. G. de; RAMOS, A. K. B.; DAVY, F. C. A.; REIS, S. F. Suplementação de bovinos mantidos em pastagens nas fases de recria e engorda. In: OLIVEIRA, R. L.; BARBOSA, M. A. A. F. (Org.). Bovinocultura de corte: desafios e tecnologias. Salvador: EDUFBA, 2007. p. 430-452.

GERDES, L. et al. Avaliação de Características de Valor Nutritivo das Gramíneas Forrageiras Marandu, Setária e Tanzânia nas Estações do Ano. Revista Brasileira de Zootecnia, v.29, n.4, p.955963, 2000.

GUYADER, J., EUGENE, M., MEUNIER, B., DOREAU, M., MORGAVI, D.P., SILBERBERG, M., ROCHETTE, Y., GERARD, C., LONCKE, C., MARTIN, C., 2015. Additive methane-mitigating effect between linseed oil and nitrate fed to cattle. J. Anim. Sci. 93, 3564-3577. https://doi.org/10.2527/jas.2014-8196.

HAMILTON, S.W.; DEPETERS, E.J.; MCGARVEY, J.A.; LATHROP, J.; MITLOEHNER, F.M. Greenhouse gas, animal performance, and bacterial population structure responses to dietary monensin fed to dairy cows. Atmospheric pollutants and trace gases. Journal of Environmental Quality, v. 39, n. 1, p.106-114, 2010.

HEINRICHS, R.; SOARES FILHO, C.V.; CRUCCIOLI, C.; FIGUEIREDO, P.A.M. de; FRUCHI, V.M.; KODEL, F.J.; RODRIGUES, T.A. Doses and sources of nitrogen fertilizer and their effects on soil chemical properties and forage yield of Brachiaria brizantha cv. Xaraés. Semina: Agrárias, Londrina, v. 33, n. 5, p. 1747-1756, 2012.

HERLING, V.R; PEDREIRA, C.G.S.; LUZ, P.D.C.; BRAGA, G.J.; MARCHESIN, W.A.; MACEDO, F.B.; DE LIMA, C.G. Performance and productivity of Nellore steers on rotationally stocked palisadegrass (Brachiaria brizantha) pastures in response to herbage allowance. The Journal of Agricultural Science, v. 149, n. 06, p. 761-768, 2011.

HODGSON, J. Herbage production and utilization. Grazing management: science into practice. New York: J. Wiley, 1990.

HRISTOV, A.N.; OH, J.; FIRKINS, J.L.; DIJKSTRA, J.; KEBREAB, E.; WAGHORN, G.; MAKKAR, H.P.S.; ADESOGAN, A.T., YANG, W.; LEE, C.; GERBER, P.J.; HENDERSON, B.; TRICARICO, J.M. Mitigation of methane and nitrous oxide emissions from animal operations: I. A review of enteric methane mitigation options. Journal of Animal Science, v.91, p.5045-5069, 2013.

HULSHOF, R.B.A.; BERNDT, A.; GERRITS, W.J.J.; DIJKSTRA, J.; VAN ZIJDERVELD, S.M.; NEWBOLD, J.R.; PERDOK, H.B. 2012. Dietary nitrate supplementation reduces methane emission in beef cattle fed sugarcane-based diets. J. Anim. Sci.90:2317-2323.

IPCC. INTERGOVERNMENTAL PANEL ON CLIMATE CHANGE. Climate change 2007: The physical science basis. In: Working group I to the fourth assessment report of the Intergovernmental Panel on Climate Change. United Kingdom and New York: Cambridge University Press, Cambridge, 2007.

JANSSEN, P. H.; KIRS, M. Structure of the archaeal community of the rumen. Applied Environmental Microbiology, v. 74, p. 3619-3625, 2008. 
JOHNSON, K.; HUYLER, M.; WESTBERG, H.; LAMB, B.; ZIMMERMAN, P. Measurement of methane emissions from ruminant livestock using a sulfur hexafluoride tracer technique. Environmental Science and Technology, v.28, p.359-362, 1994.

JOHNSON, K.A.; JOHNSON, D.E. Methane emissions from cattle. Journal of Animal Science, v. 73, n. 8, p. 2483-2492, 1995.

JOHNSON, K.A.; WESTBERG, H.H.; MICHAL, J.J.; COSSALMAN, M.W. The SF 6 tracer technique: methane measurement from ruminants. In: Makkar, H.P.S; Vercoe, P.E. (Ed) Measuring methane production from ruminants. New York: Springer, 2007. chap.3, 36p.

LEE, C., AND BEAUCHEMIN, K. A. (2014). A review of feeding supplementary nitrate to ruminant animals: nitrate toxicity, methane emissions, and production performance. Can. J. Anim. Sci. 94, 557-570. doi: 10.4141/CJAS-20 14-069.

LEE, C., ARAUJO, R.C., KOENIG, K.M., BEAUCHEMIN, K.A., 2015b. Effects of encapsulated nitrate on enteric methane production and nitrogen and energy utilization in beef heifers. J. Anim. Sci. 93 (5), 2391-2404.

LEE, C., ARAUJO, R.C., KOENIG, K.M., BEAUCHEMIN, K.A., 2015c. Effects of feed consumption rate of beef cattle offered a diet supplemented with nitrate ad libitum or restrictively on potential toxicity of nitrate. J. Anim. Sci. 93 (10), 4956-4966.

LEE, C.; ARAUJO, R.C.; KOENIG, K.M.; BEAUCHEMIN K.A. 2015a. Effects of encapsulated nitrate on eating behavior, rumen fermentation, and blood profile of beef heifers fed restrictively or ad libitum. J. Anim. Sci.93:2405-2418.

LENG, R.A. 2008. The potential of feeding nitrate to reduce enteric methane production in ruminants. A report to the department of climate change. Commonwealth Government of Australia, Canberra, Australia.

LENG, R.A.; PRESTON, T.R. Further considerations of the potential of nitrate as a high affinity electron acceptor to lower enteric methane production in ruminants. Livestock Research for Rural Development, v. 22, n. 221, 2010.

LI, L.; DAVIS, J.; NOLAN, J.; HEGARTY, R. 2012. An initial investigation on rumen fermentation pattern and methane emission of sheep offered diets containing urea or nitrate as the nitrogen source. Animal Production Science 52, 653-658.

LIN, M., D. M. SCHAEFER, W. S. GUO, L. P. REN, AND Q. X. MENG. 2011. Comparisons of in vitro nitrate reduction, methanogenesis, and fermentation acid profile among rumen bacterial, protozoal and fungal fractions. Asian-Australas J. Anim. Sci. 24:471-478.

MARTEN, G.C., BRINK, G.E. and BUXTON, D.R., 1984. Near infrared reflectance spectroscopy analysis of forage quality in four legume species. Crop Sci., 24: 1179-1 182.

MCALLISTER, T.A.; CHENG, K.J.; OKINE, E.K.; MATHISON, G.W. Dietary, environmental and microbiological aspects of methane production in ruminants. Canadian Journal of Animal Science, v. 76, n. 2, p. 231-243, 1996.

MCALLISTER, T.A.; NEWBOLD, C.J. Redirecting rumen fermentation to reduce methanogenesis. Australian Journal of Experimental Agriculture, v.48, p.7-13, 2008. 
MERTENS, D.R. Regulation of forage intake. In: FAHEY JR. G.C. (Ed.) Forage quality, evaluation, and utilization. Lincoln: University of Nebraska, p.450-493, 1994.

MINSON, D.J. Forage in ruminant nutrition. San Diego: Academic Press, Inc., p.483, 1990.

MOORE, John E.; MOTT, Gerald O. Structural inhibitors of quality in tropical grasses. Anti-quality components of forages, v. 4, p. 53-98, 1973.

MORGAVI, D. P.; FORANO, E.; MARTIN, C.; NEWBOLD, C. J. Microbial ecosystem and methanogenesis in ruminants. Animal, v. 4, p. 1024-1036, 2010.

MOTT, G.O.; LUCAS, H.L. The design, conduct, and interpretation of grazing trials on cultivated and improved pastures. In: International Grassland Congress, 6, 1952, Pennsylvania. Proceedings... Pennsylvania: State College Press, 1952. p.1380-1385.

MYERS, W.D.; LUDDEN, P.A.; NAYIGIHUGU, V.; HESS, W. Technical Note: a procedure for the preparation and quantitative analysis of samples for titanium dioxide. Journal of Animal Science, Champaign, v. 82, n. 1, p. 179-183, 2004.

NATIONAL RESEARCH COUNCIL - NRC. Nutrient requirements of beef cattle. Washington: Eighth Revised Edition. 2016. 494 p.

NEWBOLD, J.R.; VAN ZIJDERVELD, S.M.; HULSHOF, R.B.A.; FOKKINK, W.B.; LENG, R.A.; TERENCIO, P.; POWERS, W.J.; VAN ADRICHEM, P.S.J.; PATON, N.D.; PERDOK, H.B. 2014. The effect of incremental levels of dietary nitrate on methane emissions in Holstein steers and performance in Nelore bulls. J. Anim. Sci. 92, 5032-5040.

NOLAN, J.V.; HEGARTY, R.S.; HEGARTY, J.; GODWIN, I.R.; WOODGATE, R. 2010. Effects of dietary nitrate on fermentation, methane production and digesta kinetics in sheep. Anim. Prod. Sci. 50, 801- 806.

NOVAK, S.M.; FIORELLI, J.L. Greenhouse gases and ammonia emissions from organic mixed crop dairy systems: a critical review of mitigation options. Agronomy for Sustainable Development. v.30, p. 215-223, 2010.

NUSSIO, L. G.; MANZANO, R. P.; PEDREIRA, C. G. S. Valor alimentício em plantas do gênero Cynodon. In: SIMPÓSIO SOBRE MANEJO DA PASTAGEM, 15., 1998, Piracicaba. Manejo de pastagens de tifton, coastcross e estrela: anais. Piracicaba: FEALQ, 1998. p. 203-242.

NUSSIO, L.G.; SCHIMIDT, P. Forragens suplementares para bovinos de corte. In. Pires, A.V. Bovinocultura de corte. Piracicaba: Fealq, 2010 v.1, p.281-292.

ODONGO, N.E.; BAGG, R.; VASSIE, G.; DICK, P.; OR-RASHID, M.M.; HOOK, S.E.; GRAY, J.T.; KEBREAB, E.; FRANCE, J.; MCBRIDE, B.W. Long-term effects of feeding monensin on methane production in lactating dairy cows. Journal of Dairy Science, v. 90, p.1781-1788, 2007.

OLIJHOEK, D.W., HELLWING, A.L.F., BRASK, M., WEISBJERG, M.R., HØJBERG, O., LARSEN, M.K., DIJKSTRA, J., ERLANDSEN, E.J., LUND, P., 2016. Effect of dietary nitrate level on enteric methane production, hydrogen emission, rumen fermentation, and nutrient digestibility in dairy cows. J. Dairy Sci. 99 (8), 6191-6205. https://doi.org/10. 3168/jds.2015-10691.

OLIVEIRA, Y.; MACHADO, R.; POZO, P. P. del. Características botánicas y agronómicas de especies forrajeras importantes del género Brachiaria. Pastos y Forrajes, Perico, v. 29, n. 1, p. 5-28, 2006. 
PARSONS, A. J.; LEAFE, E. L.; COLLET, B. The physiology of grass production under grazing. II. Photosynthesis, crop growth and animal intake of continuously-grazed swards. Journal of Applied Ecology, v. 20, n. 1, p. 127-139, 1983.

PAULINO, M.F.; DETMANN, E.; ZERVOUDAKIS, J.T. Suplementos múltiplos para recria e engorda de bovinos em pastejo. In: SIMPÓSIO DE PRODUÇÃO DE GADO DE CORTE, 2, 2001a, Viçosa, MG. Anais...Viçosa, MG: UFV, 2001a. p. 187-231.

PIZARRO, E.A.; VALLE, C.B.; SÉLLER-GREIN, G.; SCHULTZE-KRAFT, R.; ZIMMER, A.H. Regional experience with brachiaria: Tropical America-savannas. In: MILES, J.W.; MAASS, B.L.; VALLE, C.B. (Ed.). Brachiaria: biology, agronomy and improvement. Calli: CIAT; Campo Grande: Embrapa-CNPGC, 1996. p.225-246.

PRIMAVESI, O.; FRIGHETTO, R.T.S.; PEDREIRA, M.D.S.; LIMA, M.A.D.; BERCHIELLI, T.T.; BARBOSA, P.F. Metano entérico de bovinos leiteiros em condições tropicais brasileiras. Pesquisa Agropecuária Brasileira, v.39, n.3, p.277-283, 2004.

REIS, R.A.; DA SILVA, S.C. Consumo de forragem. In: BERCHIELLI, T.T.; PIRES, A.V.; OLIVEIRA, S.G. (Eds.) Nutrição de ruminantes.2 ${ }^{\mathbf{a}}$ Ed. Jaboticabal: Funep, 83- 114, 2011.

RICHARDSON, I.; DUTHIE, C.A.; HYSLOP, J.; ROOKE, J.; ROEHE, R. Nutritional strategies to reduce methane emissions from cattle: Effects on meat eating quality and retail shelf life of loin steak. Journal of Meat Science. v.153, p.51-57, 2019.

RODRIGUES JÚNIOR, C.T.R.; CARNEIRO, M.S.S.; PEREIRA, E.S.; RODRIGUES, B.H.N.; COSTA, N.L.; PINTO, M.S.C.; ANDRADE, A.C.; PINTO, A.P.; FOGAÇA, F.H.S.; CASTRO, K.N.C. Produção e composição bromatológica do capim-Marandu em diferentes épocas de diferimento e utilização. Semina: Ciências Agrárias, v.36, n.3, p.2141-2154, 2015. Suplemento 1.

ROJAS-DOWNING, M. M.; NEJADHASHEMI, A. P.; HARRIGAN, T.; WOZNICKI, S. A. Climate change and livestock: Impacts, adaptation, and mitigation. Elservier - Climate Risk Management, v. 16, p. 145-163, 2017.

SANTOS, E.D.G.; PAULINO, M.F.; QUEIROZ, D.S.; FONSECA, D.M.; VALADARES FILHO, S.C.; LANA, R.P. Avaliação de pastagem diferida de Brachiaria decumbens Stapf. 2. Disponibilidade de forragem e desempenho animal durante a seca. Revista Brasileira de Zootecnia, v.33, n.1, p.214-224, 2004.

SANTOS, M.E.R.; FONSECA, D.M.; EUCLIDES, V.P.B.; RIBEIRO JR, J.I.; BALBINO, E.M.; CASAGRANDE, D.R. Valor nutritivo da forragem e de seus componentes morfológicos em pastagens de Brachiaria decumbens diferida. Boletim da Indústria Animal, v. 65, n. 4, p. 303-311, 2008.

SANTOS, M.E.R.; FONSECA, D.M.; EUCLIDES, V.P.B.; RIBEIRO JR., J.I.; NASCIMENTO JR., D; MOREIRA, L.M. Produção de bovinos em pastagens de capim-braquiária diferidas. Revista Brasileira de Zootecnia, v. 38, n. 4, p. 635-642, 2009.

SANTOS, M.E.R.; SILVEIRA, M.C.T.; GOMES, V.M.; FONSECA, D.M.D.; SOUSA, B.M.D.L.; SANTOS, A.D.D. Pasture height at the beginning of deferment as a determinant of signal grass structure and potential selectivity by cattle. Acta Sci. Anim. Sci., v.35, p.379-385, 2013.

SANTOS, P.M.; BERNARDI, A.C.C. Diferimento do uso de pastagens. In: SIMPÓSIO SOBRE MANEJO DA PASTAGEM, 22. 2005, Piracicaba. Anais... Piracicaba: FEALQ, 2005. p.95-118. 
SAS. STATISTICAL ANALISYS SISTEM. SAS/STAT-User's guide. 9.3. Cary, NC, USA: SAS Inst, Inc, 2013.

SBRISSIA, A.F. 2004. Morfogênese, dinâmica do perfilhamento e do acúmulo de forragem em pastos de capim-marandu sob lotação contínua. Tese de Doutorado. Escola Superior de Agricultura "Luiz de Queiroz", Universidade de São Paulo, Piracicaba. 171 p.

SEMMELMANN, C.E.N.; LOBATO, J.F.P.; ROCHA, M.D. Efeito de sistemas de alimentação no ganho de peso e desempenho reprodutivo de novilhas Nelore acasaladas aos 17/18 meses. Revista Brasileira de Zootecnia; v. 30; n. 3; p. 835-843; 2001.

SILVA, C.S.; MONTAGNER, D.B.; EUCLIDES, V.P.B.; QUEIROZ, C.D.A.; ANDRADE, R.A.S. Steer performance on deferred pastures of Brachiaria brizantha and Brachiaria decumbens. Ciênc. Rural, v.46, p.1998-2004, 2016.

SILVA, F.F.; SÁ, J.F.; SCHIO, A.R.; ÍTAVO, L.C.V.; SILVA, R.R.; MATEUS, R.G. Suplementação a pasto: disponibilidade e qualidade $\mathrm{x}$ níveis de suplementação x desempenho. Revista Brasileira de Zootecnia, Viçosa, MG, v.38, p.371-389, 2009.

SIMILI, F. F. Qualidade da pastagem na produção e composição do leite. Pesquisa \&Tecnologia, v. 9, n. 2, 2012.

SOLLENBERG, L.E.; MOORE, J.E.; ALLEN, V.G.; PEDREIRA, C.G. Reporting forage allowance in grazing experiments. Crop Science Society of America, v.45, p.896-900, 2005.

SOLOS, EMBRAPA. Sistema brasileiro de classificação de solos. Centro Nacional de Pesquisa de Solos: Rio de Janeiro, 2013.

SOUZA, A. R. D. L.; MEDEIROS, S. R.; MORAIS, M. G.; OSHIRO, M. M.; TORRES JÚNIOR, R. A. A. Dieta com alto teor de gordura e desempenho de tourinhos de grupos genéticos diferentes em confinamento. Pesquisa Agropecuária Brasileira, Brasília, v. 44, n. 7, p. 746-753, 2009.

TEIXEIRA, R. M. A.; MARTINS, J.M.; SILVA, N.G.; SILVA, E.A.; FERNANDES, L. O.; OLIVEIRA, A. S.; SALVADOR, F. M.; FARIA, D.J.G. Suplementação proteica de vacas leiteiras mantidas em pastagem de Tifton 85 durante o período de seca. Arquivo Brasileiro de Medicina Veterinária e Zootecnia, v.71, n.3, p.1027-1036, 2019.

UEBELE, M.C. 2002. Padrões demográficos de perfilhamento e produção de forragem em pastos de capim-mombaça submetidos a regimes de lotação intermitente. Dissertação de Mestrado. Escola Superior de Agricultura "Luiz de Queiroz", Universidade de São Paulo, Piracicaba. 83 p.

UNGERFELD, E.M.; KOHN, R.A. The role of thermodynamics in the control of ruminal fermentation. Ruminant physiology: digestion, metabolism and impact of nutrition on gene expression, immunology and stress, p. 55-85, 2006.

VAN SOEST, P.J., ROBERTSON, J.B., LEWIS, B.A. Methods for dietary fiber, neutral detergent fiber, and nonstarch polysaccharides in relation to animal nutrition. Journal of Dairy Science, v.74, p.3583-3597, 1991.

VAN SOEST, Peter J. Nutritional ecology of the ruminant. Cornell university press, 1994.

VAN ZIJDERVELD, S.M.; GERRITS, W.J.J.; APAJALAHTI, J.A.; NEWBOLD, J.R.; DIJKSTRA, J.; LENG, R.A.; PERDOK, H.B. 2010. Nitrate and sulfate: Effective alternative hydrogen sinks for mitigation of ruminal methane production in sheep. J. Dairy Sci. 93, 5856-5866. 
VAN ZIJDERVELD, S.M.; GERRITS, W.J.J.; DIJKSTRA, J.; NEWBOLD, J.R.; HULSHOF, R.B.A.; PERDOK, H.B. 2011. Persistency of methane mitigation by dietary nitrate supplementation in dairy cows. J. Dairy Sci. 94, 4028-4038.

VELAZCO, J.I.; COTTLE, D.J.; HEGARTY, R.S. 2014. Methane emissions and feeding behaviour of feedlot cattle supplemented with nitrate or urea. Anim. Prod. Sci. 54, 1737-1740.

VILLAR, L.; HEGARTY, R.; VAN TOL, M.; GODWIN, I.; NOLAN, J. Dietary nitrate metabolism and enteric methane mitigation in sheep consuming a protein-deficient diet. Animal Production Science, v. 60, n. 2, p. 232-241, 2020.

WANG, Z.; GOONEWARDENE, L.A. The use of MIXED models in the analysis of animal experiments with repeated measures data. Canadian Journal of Animal Science, v. 84, p. 1-11, 2004.

WASSIE, S. E.; ALI, A. I. M.; KORIR, D.; BUTTERBACH-BAHL, K.; GOOPY, J.; MERBOLD, L.; DICKHOEFER, U. Effects of feed intake level on efficiency of microbial protein synthesis and nitrogen balance in Boran steers consuming tropical poor-quality forage. Archives of animal nutrition, v.73, n.2, p. 140-157, 2019.

WESTBERG, H.H.; JOHNSON, K.A.; COSSALMAN, M.W.; MICHAEL, J.J. (1998) A SF 6 tracer technique: Methane measurement from ruminants. Washington State University, Pullman. 40.

ZEFERINO, C.V. Morfogênese e dinâmica do acúmulo de forragem em pastos de capim-marandu [Brachiaria brizantha (Hochst. ex. A. Rich) cv. Marandu] submetidos a regimes de lotação intermitente por bovinos de corte. 2006. 193f. Dissertação (Mestrado em Agronomia - Ciência Animal e Pastagens) - Escola Superior de Agronomia "Luiz de Queiroz"/Universidade de São Paulo, Piracicaba.

ZHOU, Z., Z. YU, AND Q. MENG. 2012. Effects of nitrate on methane production, fermentation, and microbial populations in in vittro ruminal cultures. Bioresour. Technol. 103:173-179. 